\title{
Farmers' perceptions of and adaptation strategies to climate change and their determinants: the case of Punjab province, Pakistan
}

\author{
M. Abid ${ }^{1,2}$, J. Scheffran ${ }^{1}$, U. A. Schneider ${ }^{3}$, and M. Ashfaq ${ }^{4}$ \\ ${ }^{1}$ Research Group Climate Change and Security, Institute of Geography, University of Hamburg, Grindelberg 7, \\ 20144 Hamburg, Germany \\ ${ }^{2}$ School of Integrated Climate System Sciences, Grindelberg 5, 20144 Hamburg, Germany \\ ${ }^{3}$ Research Unit Sustainability and Global Change, University of Hamburg, Grindelberg 5, \\ 20144 Hamburg, Germany \\ ${ }^{4}$ Institute of Agricultural and Resource Economics, University of Agriculture, Faisalabad, Pakistan
}

Correspondence to: M. Abid (muhammad.abid@uni-hamburg.de)

Received: 10 September 2014 - Published in Earth Syst. Dynam. Discuss.: 17 October 2014

Revised: 25 March 2015 - Accepted: 8 April 2015 - Published: 11 May 2015

\begin{abstract}
Climate change is a global environmental threat to all economic sectors, particularly the agricultural sector. Pakistan is one of the countries negatively affected by climate change due to its high exposure to extreme events and low adaptive capacity. In Pakistan, farmers are the primary stakeholders in agriculture and are more at risk due to climate vulnerability. Based on farm household data from 450 households collected from three districts in three agroecological zones in the Punjab province of Pakistan, this study examines how farmers perceive climate change and how they adapt their farming in response to perceived changes in climate. The results demonstrate that awareness of climate change is widespread throughout the area, and farm households make adjustments to adapt their agriculture in response to climatic change. Overall $58 \%$ of the farm households adapted their farming to climate change. Changing crop varieties, changing planting dates, planting of shade trees and changing fertilizers were the main adaptation methods implemented by farm households in the study area. The results from the binary logistic model reveal that education, farm experience, household size, land area, tenancy status, ownership of a tube well, access to market information, information on weather forecasting and agricultural extension services all influence farmers' choices of adaptation measures. The results also indicate that adaptation to climate change is constrained by several factors such as lack of information, lack of money, resource constraints and shortage of irrigation water in the study area. Findings of the study suggest the need for greater investment in farmer education and improved institutional setup for climate change adaptation to improve farmers' wellbeing.
\end{abstract}

\section{Introduction}

Climate change is a global environmental threat and development concern. Developing countries are the most adversely affected by the negative effects of climate-induced events because of their low level of adaptation (IFAD, 2010). It is projected that climate change may severely affect global food security by the middle of the 21 st century. The largest number of food-insecure people will be located in South Asia
(Hijioka et al., 2014). It is estimated that from 2001 to 2059 in South Asia, per hectare cereal yield will decline up to $30 \%$ along with an up to $37 \%$ loss of gross per capita water (Parry, 2007).

According to various studies and reports (IUCN, 2009; Kreft and Eckstein, 2013; LP, 2010), Pakistan is one of the highly affected countries by climate change. Pakistan has been ranked 12th in the Global Climate Risk Index in terms of exposure to various extreme climate events over the period 
of 1993 to 2012 (Kreft and Eckstein, 2013). The World Bank included Pakistan in the list of 12 highly exposed countries to variability in climate (Noman and Schmitz, 2011). Pakistan is an agro-based economy where agriculture contributes about $21.4 \%$ to GDP, employs around $45 \%$ of the total labor force and provides a livelihood for $62 \%$ of the rural population (Abid et al., 2011a; Farooq, 2013). Despite its significant share of the overall economy, this sector faces serious challenges from climate-change-induced impacts, i.e., rising temperatures, floods, droughts and yield losses (Noman and Schmitz, 2011).

Agriculture is the main source of support for the majority of the rural households and attached urban populations in developing countries as well as in Pakistan. Hence, adapting the agricultural sector to the negative effects of climate variability may be necessary to assure food security for the country and to protect the livelihood of rural households. Adaptation to climate change is an effective measure at the farm level, which can reduce climate vulnerability by making rural households and communities better able to prepare themselves and their farming to changes and variability in climate, avoiding projected damages and supporting them in dealing with adverse events (IPCC, 2001).

The current level of support for the agriculture sector in terms of climate change adaptation in Pakistan is very limited due to an ineffective climate policy and the very low technological and financial capacity of the country in adapting to climate change (OECD, 2011). At the national level, an integrated policy for adapting the agriculture sector to changes in climate is required (Farooqi et al., 2005). Research shows that farmers' awareness, investment in new heat-tolerant varieties, crop insurance, social awareness and protection programs may be some important aspects of the adaptation policy to climate change (Schlenker and Lobell, 2010).

Perceiving climate variability is the first step in the process of adapting agriculture to climate change (Deressa et al., 2011). A better understanding of farmers' concerns and the manner in which they perceive climate change is crucial to design effective policies for supporting successful adaptation of the agricultural sector. Further, it is also important to have precise knowledge about the type and extent of adaptation methods being taken up by farmers and need for further advances in existing adaptation setups. Hence, understanding how farmers perceive changes in climate and what factors shape their adaptive behavior is useful for adaptation research (Mertz et al., 2009; Weber, 2010). The choice of adaptation methods by farmers depends on various social, economic and environmental factors (Deressa, 2007; Bryan et al., 2013). This knowledge will ultimately enhance the credibility of policies and their strength to tackle the challenges being imposed by climate change on farmers (Deressa et al., 2009). Adaptation will require the participation of multiple players from sectors such as research and policy, those in the agricultural extension services and private welfare organiza- tions, as well as local communities and farmers (Bryan et al., 2013).

A great number of studies have been done on farm-level adaptation to climate change across different disciplines in various countries which explored farmers' adaptive behavior and its determinants (Bryan et al., 2009; Deressa et al., 2009; Hassan and Nhemachena, 2008; Thomas et al., 2007). Despite internationally extensive research on adaptation in the agriculture sector to climate change, little work has been done so far in South Asia. Similarly in Pakistan, the scope of research linking climate change to agriculture is very restricted (TFCC, 2010). To date, studies on climate change and agriculture in Pakistan have been entirely limited to impacts of climate change on particular crops or sectors (Nomman and Schmitz, 2011; Hussain and Mudasser, 2007; Hanif et al., 2010; Ashfaq et al., 2011). None of the studies considered farmers' perspectives of climate change adaptation. Hence, this study was designed to fill the existing research gap in Pakistan with respect to climate change adaptation in the agriculture sector.

This study mainly seeks to answer two research questions. First, we will look at how farmers perceive longterm changes to the local climate. Second, we will analyze how farmers adapt their farming in response to perceived changes in climate. Further, this study also considers the factors affecting farm-level adaptation methods adopted by farm households in the study area. Most of the factors affecting the farm household's choice of adaptation measures to climate change are already known, but the actual impact of these factors varies across regions. Hence, this study attempts to quantify the actual impacts of various explanatory factors on the probability of adopting different farm-level adaptation measures by farmers. The present study employs a logistic binary model to examine determinants of adaptation measures.

This paper is divided into four sections. Section 2 of the study presents a conceptual framework and empirical specification of explanatory variables. Section 3 describes the materials and method. Section 4 describes the results and discussion of the study, and in Sect. 5 we conclude our results and present some policy implications of the study.

\section{Conceptual framework and methodology}

\subsection{Description of the study area}

This study was done in the Punjab province, which is geographically located approximately at $30^{\circ} 00^{\prime} \mathrm{N}, 70^{\circ} 00^{\prime} \mathrm{E}$ in the semiarid lowlands zone (Ahmed et al., 2012). Punjab is the most populous and second largest province of Pakistan. It is a fertile agricultural region built on an extensive irrigation network and it plays a leading role in the development of the economy (Abid et al., 2011b). The province accounts for $56.2 \%$ of the total cultivated area, $53 \%$ of the total agricultural gross domestic product and $74 \%$ of the total cereal production in the country (PBS, 2011; Badar et al., 2007). 
Figure 1 shows the map of study areas located in Punjab province.

The mean annual minimum temperature in Punjab ranges from 16.3 to $18.2^{\circ} \mathrm{C}$ over the period $1970-2001$. Mean annual maximum temperature in Punjab ranges from 29.3 to $31.9^{\circ} \mathrm{C}$. The distribution of rainfall in Punjab is wideranging, mostly linked with the monsoon winds. Punjab receives $50-75 \%$ of rainfall during the monsoon season. The rain-fed zone receives the highest quantity of rainfall, followed by the rice zone, mixed zone and cotton zone, in decreasing order (Mohammad, 2005).

Based on Pakistan Agricultural Research Council's (PARC) agroecological maps (PARC, 2014), the Punjab province can be divided into 4 major and 11 subagroecological zones based on climate, agricultural production and aridity. Study districts come from three of the main agroecological zones. Study sites in the Rahim Yar Khan district are located in cotton and Cholistan sub-zones where average rainfall ranges from 72.8 to $462.5 \mathrm{~mm}$ annually. The second study district, Toba Tek Singh, is located in the central mixed zone, which receives average rainfall ranging between 219.5 and $718 \mathrm{~mm}$ annually. The third district, Gujrat, is partially located in both rain-fed and rice zones which receive average rainfall between 697 and $1401 \mathrm{~mm}$ annually (Mohammad, 2005). The average household's characteristics which play an important role in shaping the decisionmaking process in climate change adaptation vary to some extent in all three regions. For example, according to our study, the average landholding size varies between the Rahim Yar Khan (18 acres), Toba Tek Singh (14 acres) and Gujrat (16 acres) districts. Little variation is found for average household size (9-10 members) and years of schooling (89 years) in all three districts. In terms of agricultural contribution to the share of income, relatively high values are found for the districts of Rahim Yar Khan (85\%) and Toba Tek Singh (79\%), but a substantially lower value for Gujrat $(26 \%)$.

\subsection{Sampling and data collection}

To investigate the farm-level perceptions of climate change and associated choices of adaptation methods in Punjab, the selection of study districts took into account different agroecological zones (AEZs), cropping patterns, irrigation source networks and climate. In particular, the study sites in the Rahim Yar Khan district are located mainly in irrigated plains (zone A) and partially in marginal lands (zone D). The study site in the Toba Tek Singh district is located in irrigated plains (zone A). The study site in the Gujrat district is located in a rain-fed zone (zone B) (PARC, 2014).

A multi-stage sampling technique was used to select the study sites and sample farm households in the study area. In the first stage, the Punjab province of Pakistan was selected as the overall study area. In the second stage, three districts were selected from three agroecological zones based on the agriculture share of the total national economy, weather and climatic conditions, cropping patterns and irrigation networks in the area. In the third stage, two cities were selected from each district. In the fourth stage, we choose 10-13 union councils from each district depending on the number of union councils located in each district. Here, union council refers to a sub-section of the city government (tehsil) in Pakistan. In rural areas, a union council may consist of several villages. We excluded the urban union councils. In the fifth stage, two to three villages were randomly selected from each union council using Pakistan Village Statistics (Government of Pakistan, 1998) and in the sixth and last stage, six farmers were randomly selected from each village. Table 1 depicts the numbers of farmers interviewed from the study areas.

The survey was conducted between March and April in 2014. For the data collection, about 450 farmers were interviewed irrespective of gender, farm size or tenancy status through a farm household survey. Interviews were conducted for the crop year 2012-13 which includes the rabi (winter) season 2012-2013 and the kharif (summer) season of 2013. A fully structured questionnaire was used to gather information on socioeconomic characteristics, crop and domestic livestock management, land tenure, detail of farm inputs and outputs, access to various institutional services, current and past knowledge of climate change, current adaptation measures undertaken and limitations to adaptation. Prior to the study, a pretesting of the questionnaire was performed to avoid missing any important information. The enumerators received field training about the study objectives and farm household survey.

\subsection{Dependent and independent variables}

Several agricultural adaptation measures can reduce losses due to increasing temperature and decreasing precipitation (Hassan and Nhemachena, 2008). In this study, a binary logistic model was used to examine the factors influencing the choice of different adaptation measures applied by the farm households in the study area. The decision to adapt requires that farm households recognize local changes in the longterm climate such as temperature and rainfall patterns (Bryan et al., 2013).

Following previous studies by Kato et al. (2011) and Bryan et al. (2013), we assume that farm households will adapt only if they perceive a reduction in the risk to crop production or an increase in expected net farm benefits. Consider a latent variable $\left(Y_{i j}^{*}\right)$ which is equal to expected benefits from the adoption of certain adaptation measures:

$Y_{i j}^{*}=\alpha+\sum \boldsymbol{\beta}_{k} \boldsymbol{X}_{k}+\varepsilon_{Y_{i j}^{*}}$.

In this equation, $Y_{i j}^{*}$ is a latent binary variable with subscript $i$ depicting the household who adapted to climate variability and $j$ depicting eight different adaptation measures. $\boldsymbol{X}_{k}$ represents the vector of exogenous explanatory variables that influence the farmers' choice of adopting particular adaptation 


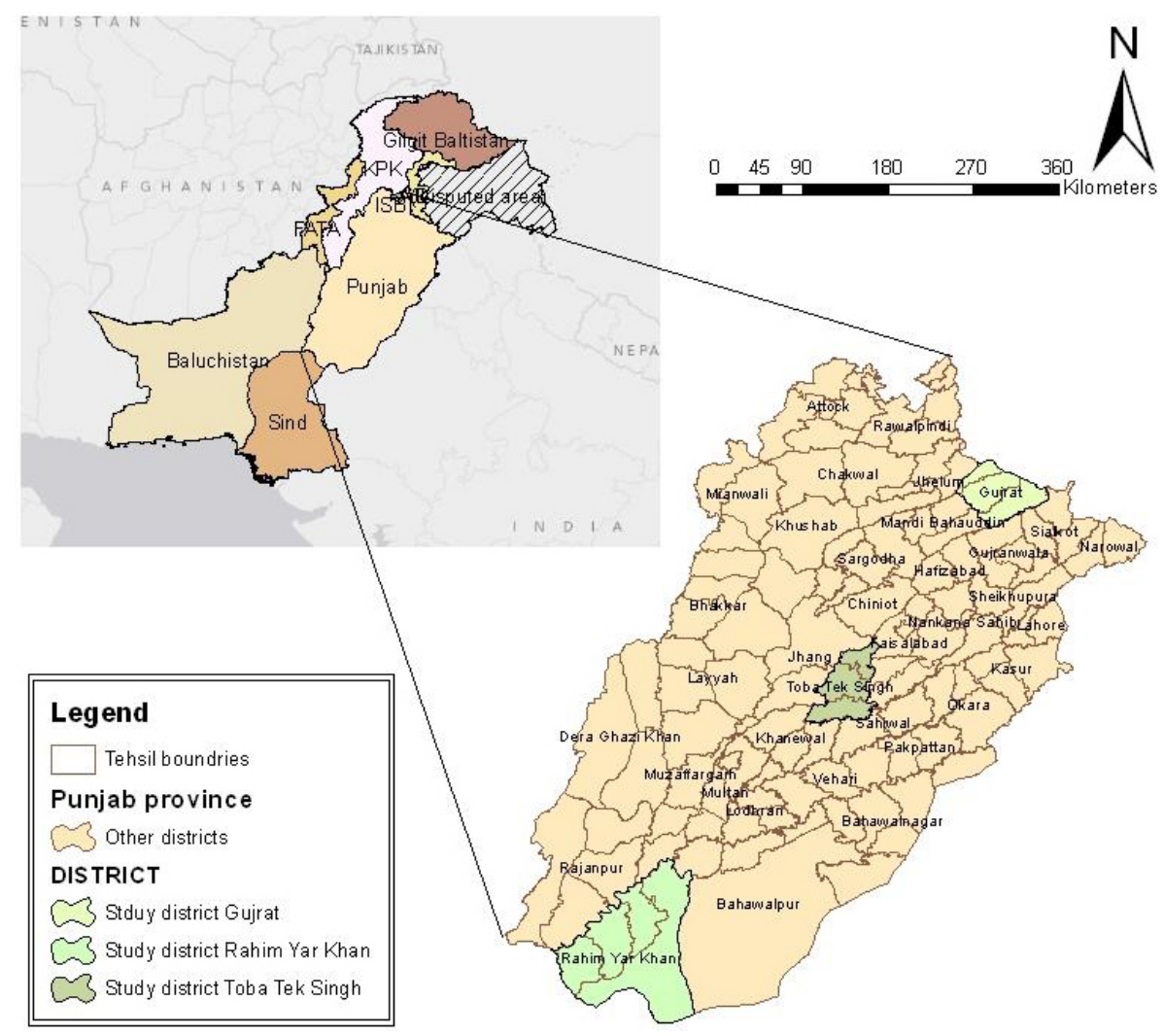

Figure 1. Sample study districts in Punjab province, Pakistan.

Table 1. The study districts.

\begin{tabular}{llcc}
\hline Districts & $\begin{array}{l}\text { City } \\
\text { (Tehsil) }\end{array}$ & $\begin{array}{c}\text { Union } \\
\text { councils } \\
\text { selected }\end{array}$ & $\begin{array}{c}\text { No. of } \\
\text { farmers } \\
\text { interviewed }\end{array}$ \\
\hline Rahim Yar Khan & Khanpur & 4 & 75 \\
& Liaqatpur & 6 & 75 \\
\hline Toba Tek Singh & Toba Tek Singh & 6 & 75 \\
& Gojra & 6 & 75 \\
\hline Gujrat & Gujrat & 7 & 75 \\
& Kharian & 6 & 75 \\
\hline Total & & 35 & 450 \\
\hline
\end{tabular}

measures and $k$ in the subscript shows the specific explanatory variable (varies from zero to 14 ). The symbol $\alpha$ denotes the model intercept, $\boldsymbol{\beta}_{k}$ the vector of binary regression coefficients and $\varepsilon_{Y_{i}^{*}} \cong N\left(0, \sigma^{2}\right)$ is the error term which is normally distributed and homoscedastic (zero mean and constant variance; Schmidheiny, 2013).
We do not observe the latent variable $\left(Y_{i j}^{*}\right)$ directly. All we observe is

$$
Y_{i j}= \begin{cases}1 & \text { if } Y_{i j}^{*}>0 \\ 0 & \text { if } Y_{i j}^{*} \leq 0,\end{cases}
$$

where $Y_{i j}$ is an observed variable which indicates that household $i$ will opt for certain measures $j$ (Fig. 4) to adapt to perceived changes in climate $\left(Y_{i j}=1\right)$ if their anticipated benefits are greater than zero $\left(Y_{i j}^{*}>0\right)$, and otherwise household $i$ will not choose adaptation measure $j$ if the expected benefits are equal to or less than zero $\left(Y_{i j} \leq 0\right)$.

Hence, we can interpret Eq. (2) in terms of the observed binary variable $\left(Y_{i j}\right)$ as

$\operatorname{Pr}\left(Y_{i j}=1\right)=Y_{i j}=G\left(X_{k} \beta_{k}\right)$,

where $G($.$) takes the specific binomial distribution (Ferni-$ hough, 2011).

\subsection{Marginal effects and partial elasticities}

The estimated parameters $\left(\beta_{k}\right)$ of the binary logistic model only give the direction of the effect of the independent variables on the binary dependent variable and statistical significance associated with the effect of increasing an independent variable just like ordinary least square (OLS) coefficients (Peng et al., 2002). Thus, a positive coefficient $\beta_{k}$ 
Table 2. Description of explanatory variables used in the model.

\begin{tabular}{|c|c|c|c|c|}
\hline Explanatory variable & Mean & SD & Description & $\begin{array}{c}\text { Expected } \\
\text { signs }\end{array}$ \\
\hline Years of experience in farming & 24.37 & 11.97 & Continuous & $(+)$ \\
\hline Years of education & 8.510 & 4.256 & Continuous & $(+)$ \\
\hline Household size (individuals) & 9.664 & 5.133 & Continuous & $(+)$ \\
\hline Landholding (acres) & 16.06 & $28.53^{*}$ & Continuous & $(+)$ \\
\hline Livestock ownership & 0.607 & 0.489 & Dummy takes the value 1 if owned and 0 otherwise & $(+)$ \\
\hline Tube well ownership & 0.630 & 0.482 & Dummy takes the value 1 if owned and 0 otherwise & $(-)$ \\
\hline Distance from local market (kilometers) & 9.089 & 7.610 & Continuous & $(-)$ \\
\hline Access to credit & 0.096 & 0.294 & Dummy takes the value 1 if have access and 0 otherwise & $( \pm)$ \\
\hline Agricultural extension services provided for crop and livestock production & 0.260 & 0.439 & Dummy takes the value 1 if have access and 0 otherwise & $(+)$ \\
\hline Information on weather forecasting & 0.836 & 0.371 & Dummy takes the value 1 if have access and 0 otherwise & $(+)$ \\
\hline Access to marketing information & 0.762 & 0.426 & Dummy takes the value 1 if have access and 0 otherwise & $(+)$ \\
\hline Access to information on water delivery & 0.784 & 0.412 & Dummy takes the value 1 if have access and 0 otherwise & $( \pm)$ \\
\hline Irrigated plains cotton zone (base rain-fed zone) & 0.330 & 0.472 & Dummy takes value 1 if district Rahim Yar Khan and 0 otherwise & $( \pm)$ \\
\hline Irrigated plains mixed crop zone (base rain-fed zone) & 0.330 & 0.472 & Dummy takes value 1 if district Toba Tek Singh and 0 otherwise & $( \pm)$ \\
\hline
\end{tabular}

* This large standard deviation is due to presence of large land holders in Rahim Yar Khan district.

shows that an independent variable $X_{k}$ increases the likelihood that $Y_{i j}=1$ (which is the adoption of a particular adaptation measure in our case). But this coefficient cannot explain how much the probability of household $i$ adopting a particular adaptation measure $\left(Y_{i j}=1\right)$ will change when we change $X_{k}$, i.e., the coefficient $\left(\beta_{k}\right)$ does not show the magnitude of the effect of a change in explanatory variable $X_{k}$ on $\operatorname{Pr}\left(Y_{i j}=1\right)$. Thus, to interpret and quantify the results, we need to calculate either marginal effects or partial elasticity. Marginal effects $\left(y_{i j}^{\prime}\right)$ describe the effect of a unit change in the explanatory variable on the probability of a dependent variable, i.e., $\operatorname{Pr}\left(Y_{i j}=1\right)$. Derivation of marginal effects is discussed in detail in Appendix A. The final equation of the marginal effect $\left(y_{i j}^{\prime}\right)$ after derivation becomes

$y_{i j}^{\prime}=\operatorname{Pr}\left(Y_{i j}=1\right) \cdot\left(1-\operatorname{Pr}\left(Y_{i j}=1\right)\right) \beta_{k}$.

Another alternative to interpret the results of a logistic regression is to use partial elasticities which measure the percentage change in probability of the dependent variable (adoption of certain adaptation measure to climate variability) due to a $1 \%$ increase in the explanatory variable $X_{k}$ (see Appendix A for further details). We may interpret the partial elasticity of the logit model calculated at mean as

$\eta_{Y}\left(\overline{X_{k}}\right)=\beta_{k} \overline{X_{k}} \operatorname{Pr}\left(Y_{i j}=1\right) \cdot\left(1-\operatorname{Pr}\left(Y_{i j}=1\right)\right)$.

\subsection{Description of explanatory variables}

The choice of explanatory (independent) variables used in this study is based on data availability and review of the literature. The independent variables include household characteristics (e.g., farming experience of household head, household head's education, size of household, tube well ownership, landholding and tenancy status of the farm household), institutional factors (e.g., access to credit, market information, weather forecasting information, information on water delivery, agricultural extension services), and dummies for agroecological zones. Instead of using agroecological factors (e.g., temperature and rainfall) and cultural traits in different regions directly, we used dummy variables for agroecological and cultural settings given the absence of variability in temperature and rainfall for households in the same district.

Prior to the survey, a multinomial logit (MNL) modeling approach was proposed based on literature where most of the previous studies of farmers' adaptation to climate change employed the MNL approach (Deressa et al., 2009; Hassan and Nhemachena, 2008; Hisali et al., 2011), where respondents are restricted to select only one from a given set of adaptation measure. However, in the course of this study, we frequently found that farm households adopted more than one adaptation measure simultaneously. This behavior made the use of the MNL approach inappropriate. A possible remedy would be to combine similar measures into single categories (Bryan et al., 2013). However, such grouping into self-defined categories may lead to misinterpretation (Bryan et al., 2013). Furthermore, the set of explanatory variables influencing the farmers' decision was also expected to be different for different adaptation measures. Therefore, we employed the logistic regression technique to examine the factors that affect the choice of adaptation measures. Table 2 shows the description and expected signs of explanatory variables used in this study.

\subsection{Hypothesis testing for model significance}

We tested all of our models for significance and accuracy of predictions. There are different ways to measure goodness of fit for logistic models. In the first step, we used the classification table method to measure the extent to which our models accurately predict the dependent variable (in our case, adoption of the particular adaptation measure by the farm household). The classification table is calculated by comparing the predicted scores of observations, on the basis of independent variables in our model, with their actual responses given in the data (Hosmer Jr. and Lameshow, 2004). Higher percentages indicate a better fit of the model. The results of the classification table test (Table 3 ) show that the overall percentage 
correctness for all models is above $71 \%$ which confirms the better fit of all of the models used in this study.

In the second step, to test the overall significance of models, we used a global null hypothesis approach. For this analysis, we established a null hypothesis by assuming and setting all the regression coefficients of logistic models equal to zero versus the alternative that at least one of the regression coefficients $\left(\beta_{k}\right)$ is not zero (Peng et al., 2002):

$H_{0}: \beta_{k}=0$,

$H_{1}$ : at least one $\beta_{k} \neq 0$.

This approach is the same as the $F$ test for model testing in OLS regression. This test checks whether the model with predictors, i.e., Eq. (1), fits significantly better than the model with just an intercept (i.e., an intercept-only model):

$Y_{i j}^{*}=\alpha$.

The test statistic is calculated by taking the difference of the residual deviance for the model with predictors or independent variables from the null deviance of intercept-only model. The test statistic is distributed $\chi^{2}$ with a degree of freedom that is equal to the differences between the number of variables in the model with predictors and intercept-only model (Stephenson et al., 2008).

From Table 3 , it can be examined that $\chi^{2}$ values for all adaptation models are positive and vary between 28 and 65 . The associated $p$ values are less than 0.001 except in the model for crop diversification that is significant at $p$ value 0.01 from which it can be concluded that our models with predictors fit significantly better than the intercept-only model. Hence, on the basis of test statistics, we can reject the null hypothesis $\left(H_{0}\right)$ and accept the other alternative hypothesis $\left(H_{1}\right)$ that at least one of the regression coefficients $\left(\beta_{k}\right)$ is not zero.

Further, we calculated the pseudo- $R^{2}$ measure to determine the goodness of fit of our adaptation models. The values of pseudo- $R^{2}$ for all models ranged from 0.15 to 0.28 which indicate a better fit of our models in explaining adaptation to climate variability.

Based on the results from the classification table, global null hypothesis and pseudo- $\mathrm{R}^{2}$, it can be assumed that all the models selected for this study are fit and can accurately estimate the factors affecting the adoption of different adaptation methods.

\section{Results and discussion}

\subsection{Farm-level perceptions of climate change}

As discussed above, farmers' perceptions of long term or short term changes in climate are a crucial pre-indicator in the adaptation process (Adger et al., 2009). Hence, respondents were asked how they perceive long-term changes in climate indicators in their area.
The study results (Fig. 2a) indicate that the large number of farmers perceived a slight increase in temperature for both summer $(56.9 \%)$ and winter seasons $(39.3 \%)$. In perceiving the precipitation patterns, the percentage of farmers who reported a slight decrease in precipitation in both summer (44\%) and winter (48.9\%) seasons are more than the farmers who perceived significant or no change in both summer and winter seasons (Fig. 2b). The majority of the surveyed farmers $(52.2 \%)$ perceived an increase in growing season length for the rabi season, while $57.1 \%$ of the farmers observed no change in growing season length for the kharif season (Fig. 2c).

Farm-level perceptions of the majority of farmers about climate indicators in both summer and winter seasons are in accordance with actual trends presented in Fig. 3a and b. According to Fig. 3a, the mean temperature in winter and summer season shows a significant slight increase over the period of 1990-2010, while Fig. 3b depicts a slight decrease in winter and summer precipitation over the same period.

\subsection{Farm-level adaptation process}

In our study, we also analyzed the whole adaptation process across all three study districts (Fig. 4). The results show that overall and across districts there is a substantial reduction in the number of responses of farmers, from perceptions of changes in climate to the final adaptation to climate change. In the first stage (perception stage), overall $81 \%$ of the respondents indicated climate change, with the highest perception in Gujrat district $(86 \%)$ and the lowest in Rahim Yar Khan $(73 \%)$. In the second stage (intention stage), overall $75 \%$ of the farmers showed their intentions to adapt to climate change with the highest intentions in Gujrat district (85\%) and the lowest in Rahim Yar Khan (66\%). In the third and last stage (adaptation process), overall only $58 \%$ of the respondents adapted to climate variability with greatest adaptation in Gujrat district $(70 \%)$ and the least in Rahim Yar Khan $(49 \%)$. In Toba Tek Singh district, about $55 \%$ of the farm households adapted their farming in response to climate variability. As can be observed from the results, from perception stage to intention stage on average a drop from 81 to $75 \%$ was observed in responses while from intention stage to adaptation stage, responses of farm households dropped from 75 to $58 \%$ on average. In the same way, moving from perception stage to adaptation stage, farmers' responses dropped from 81 to $58 \%$. From the results, it can be determined that the number of farmers who adapted to climate change is substantially less than the farmers who perceived some form of climatic risk or planned to adapt in earlier stages of the adaptation process. This reduction in numbers may be associated with various constraints, and internal or external factors explained in the next section. 
Table 3. Hypothesis testing for model significance and predictive power.

\begin{tabular}{|c|c|c|c|c|c|c|c|}
\hline Models & $\begin{array}{c}\chi_{2} \\
\text { (Chi-squared) }\end{array}$ & Degree of freedom $(\mathrm{df})$ & $\begin{array}{c}P \\
\text { level }^{b}\end{array}$ & $\begin{array}{c}-2 \log \\
\text { likelihood }\end{array}$ & $\mathrm{AIC}^{\mathrm{a}}$ & $\begin{array}{c}\text { Model } \\
\text { correctness }^{\mathrm{c}} \\
(\%)\end{array}$ & $\begin{array}{c}\text { Nagelkerke } \\
\text { pseudo- } \\
R^{2}\end{array}$ \\
\hline Changing crop type & 65.18 & 14 & 0.00 & -115.89 & 261.77 & 89.90 & 0.28 \\
\hline Changing crop variety & 64.91 & 14 & 0.00 & -250.38 & 530.77 & 71.30 & 0.19 \\
\hline Changing planting dates & 66.99 & 14 & 0.00 & -235.20 & 500.40 & 76.40 & 0.20 \\
\hline Planting shade trees & 68.55 & 14 & 0.00 & -220.41 & 470.82 & 76.40 & 0.21 \\
\hline Soil conservation & 56.71 & 14 & 0.00 & -188.25 & 258.07 & 91.10 & 0.22 \\
\hline Changing fertilizer & 46.52 & 14 & 0.00 & -114.04 & 406.51 & 83.60 & 0.19 \\
\hline Irrigation & 42.51 & 14 & 0.00 & -122.82 & 275.65 & 90.40 & 0.19 \\
\hline Crop diversification & 28.19 & 14 & 0.01 & -106.40 & 242.81 & 92.40 & 0.15 \\
\hline
\end{tabular}

${ }^{\mathrm{a}}$ AIC (Akaike information criterion) measures the relative quality of the statistical mode. ${ }^{\mathrm{b}} P$ level shows the statistical significance to reject the null hypothesis $\left(H_{0}\right)$.

${ }^{\mathrm{c}}$ based on the classification table.

(a)

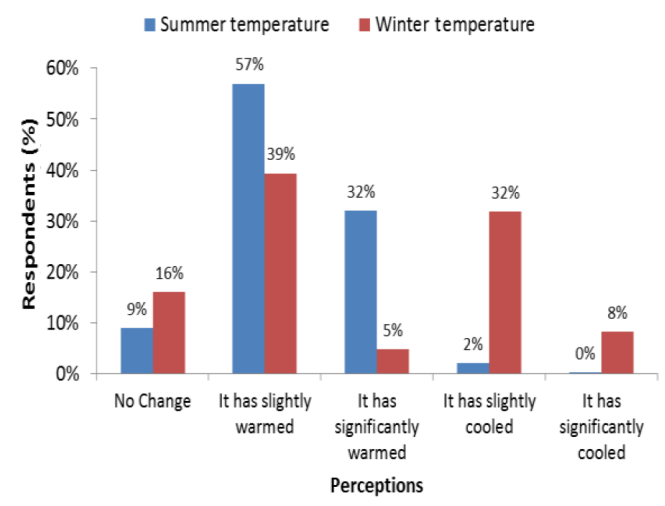

(b)

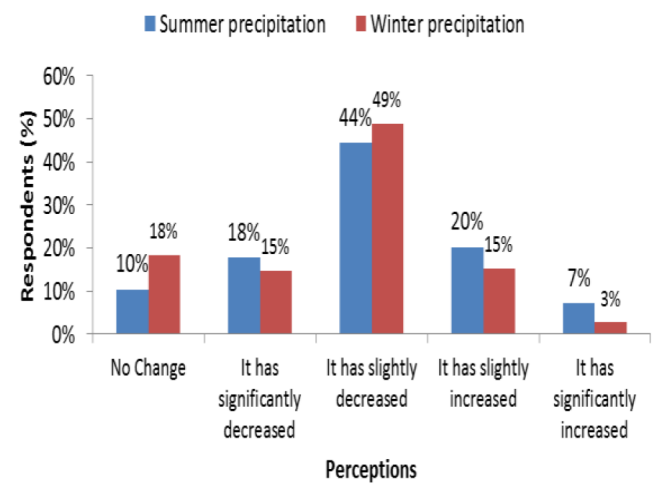

(c)

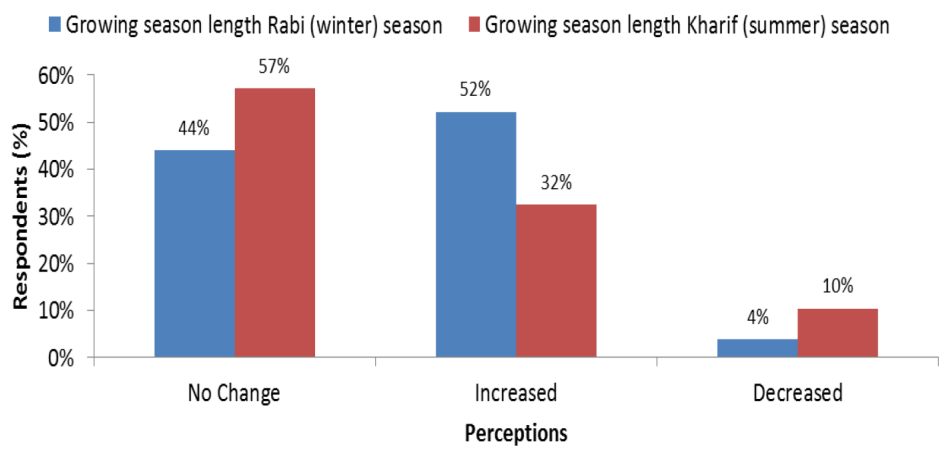

Figure 2. (a-c) Farmers' perceptions of climate change in study area of Punjab province, Pakistan.

\subsection{Farm-level adaptation strategies and constraints}

Farmers who observed variability in the climate over the period of 10 to 20 years were further asked to describe the farm-level adaptation measures undertaken in response to climate change. The results of the study demonstrated that farm households applied a wide range of adaptation measures in response to the changes in climate. As shown in Fig. 5, the most common adaptation measures were changing crop va- rieties $(32.20 \%)$, changing planting dates $(28.40 \%)$, planting shade trees $(25.30 \%)$ and changing fertilizers $(18.70 \%)$ followed by changing crop types $(10.20 \%)$, increasing irrigation $(9.80 \%)$, soil conservation $(9 \%)$, crop diversification $(7.56 \%)$, migration to urban areas $(3 \%)$ and renting out land $(2.20 \%)$. Greater use of changing crop varieties and changing planting dates as adaptation measures could be associated with ease of access and low cost of adaptation method by farmers. The lesser use of renting out of land and migration 
(a)

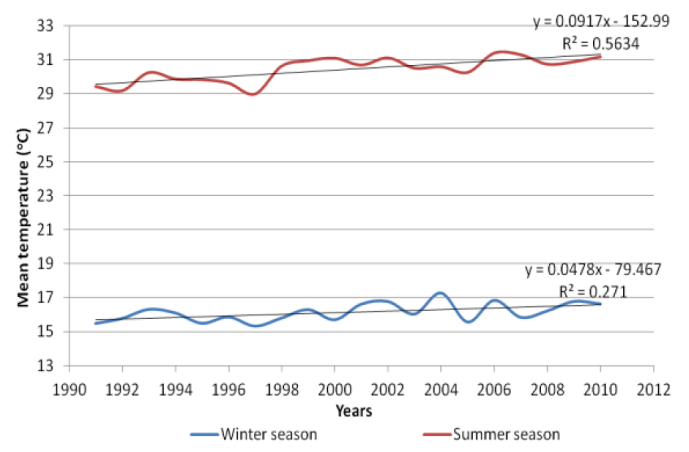

(b)

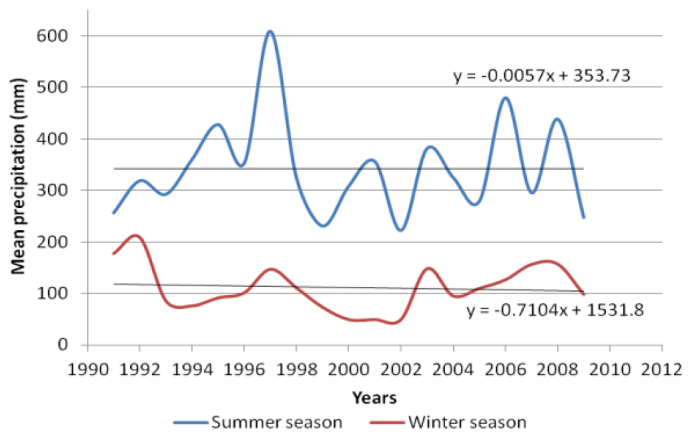

Figure 3. Mean temperature (a) and precipitation (b) trends in study area over the period of 1990-2010.

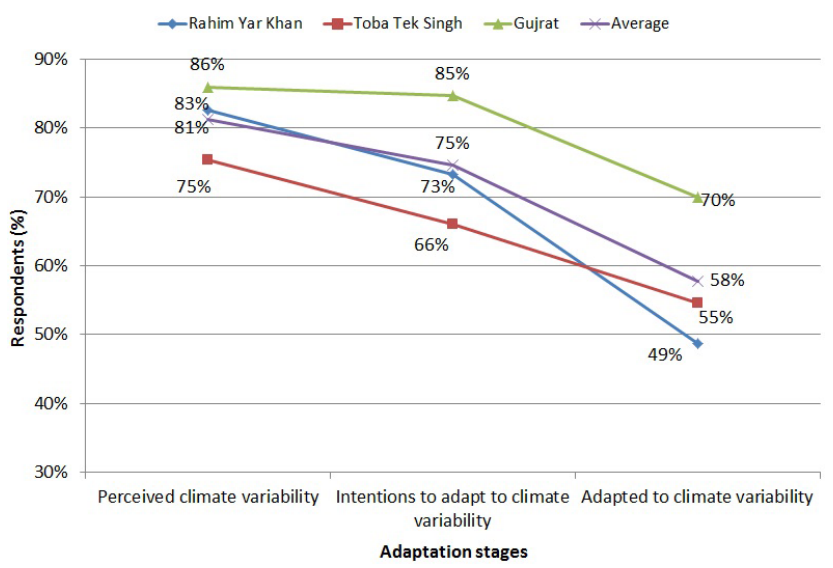

Figure 4. Perceptions, intentions and adaptation to climate change across different study districts.

to urban areas may be attributed to the fewer opportunities in urban areas or other sectors for unskilled farmers.

Implementation of adaptation measures by farm households varied across the three study districts (Fig. 5). In the Gujrat district, major adaptation measures adopted by farmers included the use of different crop varieties (39\%), changing planting dates $(36.70 \%)$, planting shade trees $(31.30 \%)$ and changing fertilizers (24\%). The main reason for changing crop variety, planting dates and shade trees may be due to more dependence of farming on rain and groundwater for cultivation of crops in the Gujrat district. That is why farmers need to modify their farming behaviors according to the variability in climate. In Toba Tek Singh district, changing crop variety $(36 \%)$, changing planting dates $(17.30 \%)$ and planting shade trees $(17.30 \%)$ were the primary adaptation measures. In Rahim Yar Khan, farmers mainly used changing planting dates $(31.30 \%)$, planting shade trees $(27.30 \%)$, changing crop variety (22\%), changing fertilizer (20\%) and changing crop types $(18 \%)$ as the adaptation measures in a changing climate (Fig. 5).
Moreover, we identified a number of constraints faced by the farmers who perceived long-term changes in climate and intended to adapt their farming in the second stage of the adaptation process, but did not adapt their farming in the third stage of the adaptation process. The major constraints identified by the majority of the respondents (Fig. 6) were lack of information (44\%) and lack of money (22\%) followed by resource constraints $(17 \%)$, shortage of irrigation water $(14 \%)$ and other constraints $(2 \%)$. Lack of information deals with less information access by the farmers either from private or public sources about how to modify their agriculture in the case of extreme weather events, including high rainfall, water stress at sowing stage, extreme high or low temperatures which are frequently mentioned as indicators of climate change. Farmers showed their intention to adopt particular adaptation measure in the case of extreme weather events but did not manage to adapt due to improper information either about the adaptation method or usefulness of certain adaptation for their crops.

Lack of money is identified by responding farmers as another key constraint for adaptation, even if they plan to adapt to climate variability. Use of farm credit in the study sites is limited, despite access to microcredit facilities available at the town level. High credit interest rates are one of the reasons for minimal attraction of farmers to credit institutions. Less access to or availability of resources at farm-level constrains the capability of adapting to climate change. Physical resources may include farm inputs (improved seed, fertilizers), farm implements (tools for soil conservation, cultivators, harvesters etc.) and institutional resources (water and soil testing laboratories).

Further, we asked farmers to identify best measures to enhance effective adaptation to climate variability. Respondent farmers identified the provision of subsidies on farm inputs, updated farm information services and sufficient irrigation water supply as necessary means to enhance the adaptation of agriculture to climate variability in the study area. 


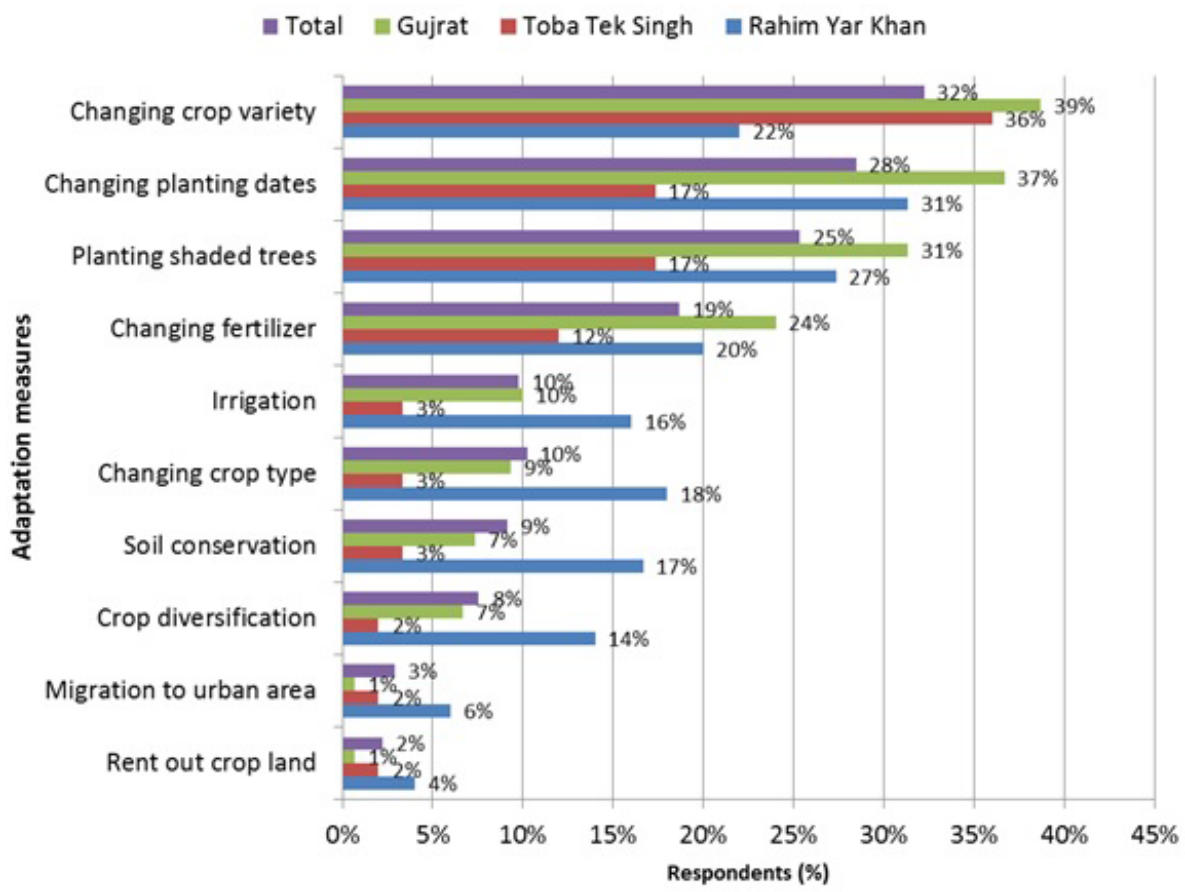

Figure 5. Adaptation measures adopted by farmers across three study areas in Punjab, Pakistan.

\subsection{Adaptation to climate variability across regions and different farm characteristics}

From the results of the adaptation process explained above in Sect. 3.2 and Fig. 9, we can observe that farm-level adaptation processes (perceptions, intentions and adaptation) are influenced by various factors. These adaptation measures can be further explored based on different characteristics of farm households or their location. Hence, we assume that perceptions, intentions and final decisions of adapting to climate change all differ in terms of extent to choose different adaptation measures. To analyze this variation, we categorize the farm households on the basis of education and farming experience. On the basis of education, we divided farmers into three categories: illiterate farmers without formal education; farmers with 1 to 10 years of schooling; and farmers with more than 10 years of schooling (Fig. 7). In terms of farming experience, we again divided farmers into three categories, i.e., farmers with less than 10 years of experience in farming; farmers with 10-20 years of farming experience, and farmers with more than 20 years of experience.

From the results shown in Fig. 7, it can be observed that moving from a lower to higher education level leads to an increase in the perception, intentions to adapt and final adaptation to climate change in all study districts. Overall, farmers with more than 10 years of schooling were more likely $(44.2 \%)$ to perceive changes in climate over the past 1020 years than farmers with less than 10 years of schooling $(25.8 \%)$ or no education $(11.3 \%)$. In the case of intentions to adapt, farmers with less than 10 years of schooling (23.6\%)

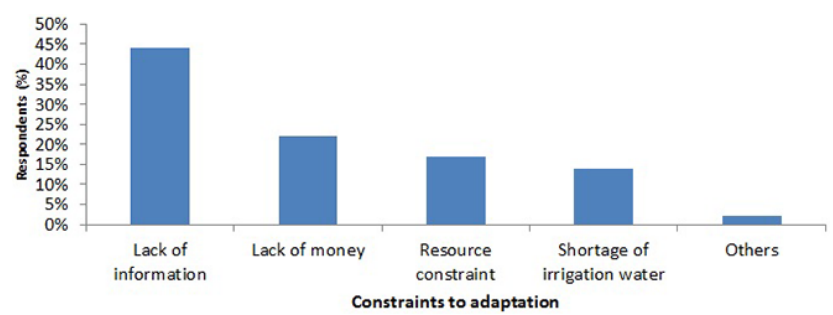

Figure 6. Constraints to adaptation to climate change in the study area.

or no education $(10.9 \%)$ were less willing to adapt compared to farmers with more than 10 years of schooling $(40.2 \%)$. The same was found true in the case of adaptation to climate change where more than $31 \%$ of the farmers who adapted to climate change had more than 10 years of schooling, and $18.2 \%$ of the farmers had education between 1 and 10 years. Adaptation was the lowest in the case of illiterate farmers who were the only $8.4 \%$ of the total sampled farmers who adapted to climate change. The same trend can be observed for all three study districts with little variation (Fig. 7).

The analysis of adaptation measures across different categories of farmers based on farming experience is explained in Fig. 8. Farmers with more than 20 years of experience were more likely $(40.9 \%)$ to perceive variability in climate than farmers with experience between 10 and 20 years $(28.2 \%)$ or farmers with less than 10 years of experience (12.2\%). Similar results were obtained for both intentions to adapt and final adaptation to climate change. Overall, farmers with more 


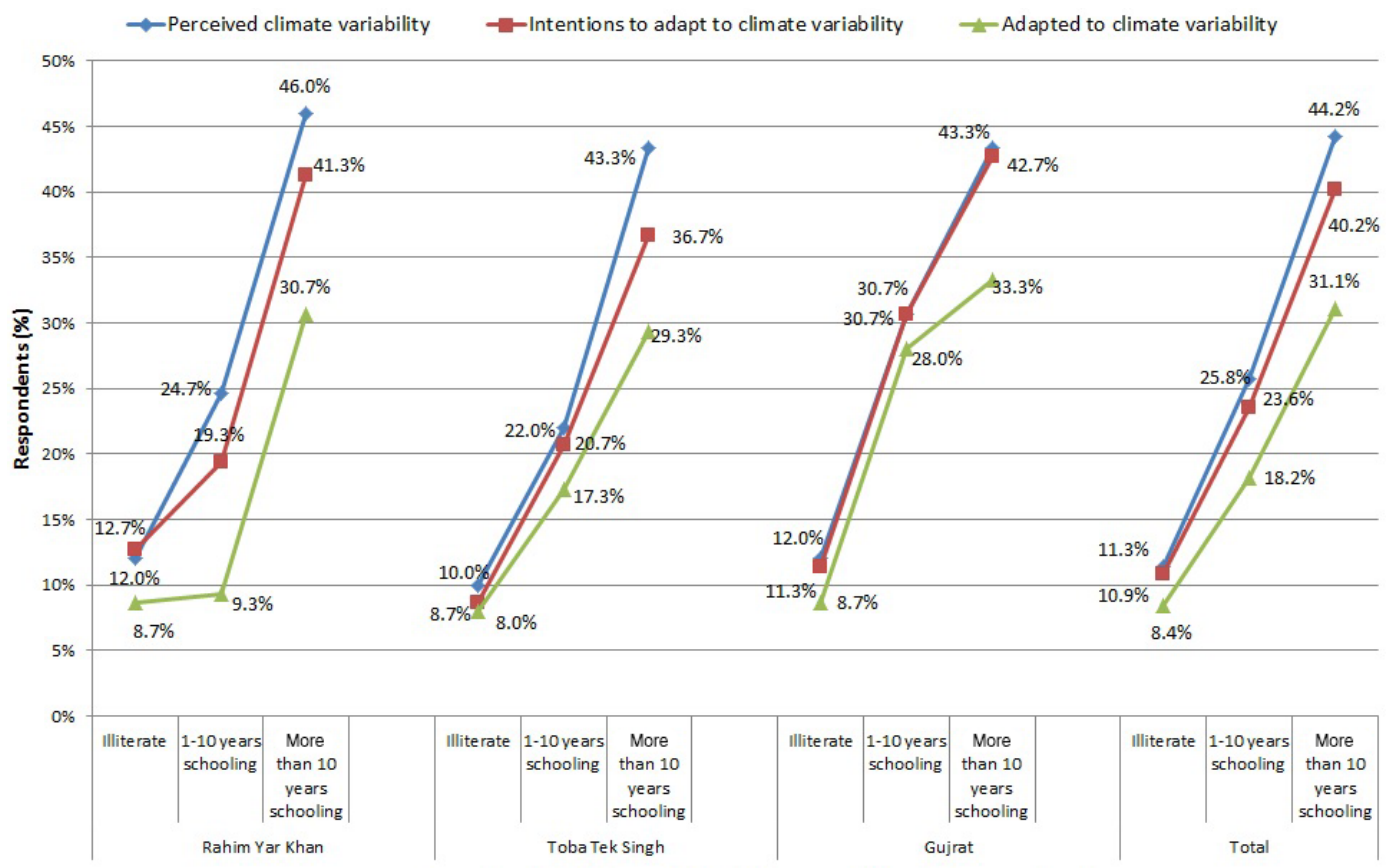

Perceptions, intentions and adaptation across different literacy categories

Figure 7. Adaptation to climate variability across different categories of farmers based on education level.

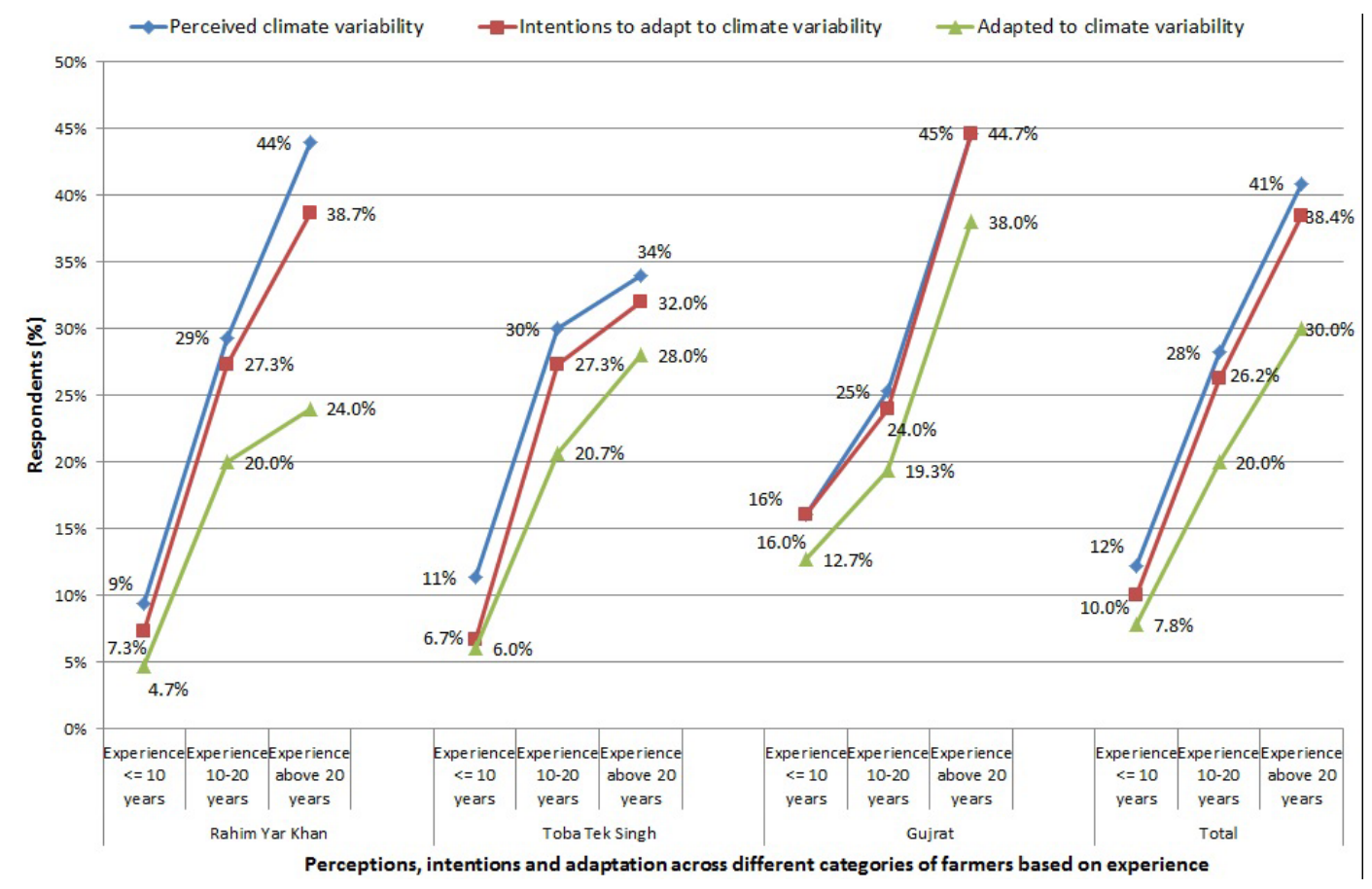

Figure 8. Perceptions, intentions and adaptation to climate change across different categories of farmers on farming experience in Punjab.

than 20 years of farming experience $(38.4 \%)$ have greater intentions to adapt compared to the farmers in the other two groups, i.e., farmers with experience between 10 and 20 years $(26.2 \%)$ and farmers with less than 10 years of experience $(10 \%)$. Farmers with more than 20 years of farming experi- ence were the $30 \%$ of the total farmers who adapted to climate change, while farmers with experience between 10 and 20 years $(20 \%)$ and farmers with less than 10 years of experience $(7.8 \%)$ adapted less. Figure 8 shows the same pattern for all districts. In summary, the higher the level or education 
and farming experience for a given household, the higher its probability of adaptation to climate change.

\subsection{Factors affecting adaptation measures}

To quantify the impact of various explanatory factors affecting farmers' choice of adaptation methods, we used logistic regression models for all adaptation measures. The coefficients of logistic regression that tell us about the direction of effect of independent variables are presented in Table 4 and the marginal effects that explain the effect of a unit change in explanatory variables on the dependent variable are shown in Table 5. Finally partial elasticity calculations to elaborate the percentage impact of various factors on the probability of different adaptation measures are described in Table 6. For continuous variables, we described the results in marginal form from Table 5, while for the binary variables, we used the elasticities for interpretation of results from Table 6. In the following sub-sections, we describe the impact of various explanatory variables on the probabilities of adopting different adaptation measures in response to variability in climate.

\subsubsection{Years of experience in farming}

The coefficient of years of experience in farming has a positive sign for most of the adaptation measures, indicating a positive relation between farming experience and possibility of adapting to climate change. According to results in Table 4, years of farming experience significantly increases the probability of choosing changing crop varieties, changing planting dates and changing fertilizer as adaptation measures. Elasticity calculations in Table 6 show that a $1 \%$ increase in the years of experience increases the probability of adopting changing crop variety $(0.14 \%)$, changing planting dates $(0.15 \%)$ and changing fertilizer $(0.11 \%)$ as adaptation measures. The results of the study are in accordance with those from Maddison (2007) and Nhemachena and Hassan (2007) which also found a positive relationship between farming experience and adaptation to climate change. Hence, it can be concluded that farmers with greater farming experience are likely to be more aware of past climate events and better judge how to adapt their farming to extreme weather events.

\subsubsection{Education}

Education is assumed to be an important factor in accessing advanced information on new improved agricultural technologies and increased agricultural productivity (Norris and Batie, 1987; Elahi et al., 2015). In our study, the highly significant coefficient of education of the household head shows that the probability of adapting to changes in climate increases with an increase in the years of schooling (Table 4). The elasticities in Table 6 show that $1 \%$ increase in the years of schooling of household head would lead to an increase in the probability of changing crop type $(0.08 \%)$, changing crop variety $(0.09 \%)$, changing planting dates $(0.17 \%)$, planting shade trees $(0.08 \%)$, soil conservation $(0.08 \%)$, changing fertilizer $(0.15 \%)$ and irrigation $(0.09 \%)$ as adaptation measures to climate variability. Various studies (Bryan et al., 2013; Deressa et al., 2009; Maddison, 2007) also found a significant positive relationship between education of household head and adaptation to climate change that supports the finding of this study. Hence, it can be concluded that farmers with more years of schooling are more likely to adapt to changes in climate compared to the farmers with little or no education.

\subsubsection{Household size}

A positive coefficient of household size indicates a positive relationship between household size and probability of adaptation (Table 4). For instance, an increase by one individual in the average household would lead to a $0.25 \%$ increase in the likelihood of planting shade trees and $0.47 \%$ increase in choice of soil conservation as adaptation measure (Table 5). Findings of the studies of Croppenstedt et al. (2003) and Deressa et al. (2009) also support our findings of a positive relationship between household size and adoption of agricultural technology or adaptation to climate change.

\subsubsection{Land area}

Land area represents the total land area held by a farm household and may be taken as a proxy for farm household wealth. The results in Table 4 indicate that the land area has positive and significant impacts on changing crop varieties and crop types. A $1 \%$ increase in the land area increases these probabilities of changing crop type and changing crop varieties by 0.01 and $0.06 \%$, respectively (Table 6).

\subsubsection{Tenancy status}

Tenancy status indicates farmers' land tenure status as owner or tenant. In this study, tenancy status has a negative sign for most of the adaptation measures which indicate that tenants are more likely to adapt their farming to perceived climate change compared to the self-operating farmers (owners). This can be observed from marginal effects presented in Table 5 that if the farmer is the owner, it reduces the probability of changing crop type $(9.29 \%)$, changing planting dates $(7.64 \%)$ and changing fertilizers $(9.77 \%)$. Increased likelihood of adaptation for tenants may be due to the reason that tenants are more conscious about their farm income compared to owners as the former also has to pay the rent of land hence they will adapt more to climate change to keep their gross revenue above total cost as compared to owners. 
Table 4. Parameter estimates of the logistic regression models of farm-level adaptation measures.

\begin{tabular}{|c|c|c|c|c|c|c|c|c|}
\hline Explanatory variables & $\begin{array}{r}\text { Changing } \\
\text { crop } \\
\text { type }\end{array}$ & $\begin{array}{r}\text { Changing } \\
\text { crop } \\
\text { variety }\end{array}$ & $\begin{array}{r}\text { Changing } \\
\text { planting } \\
\text { dates }\end{array}$ & $\begin{array}{r}\text { Planting } \\
\text { shade } \\
\text { trees }\end{array}$ & $\begin{array}{r}\text { Soil } \\
\text { conservation }\end{array}$ & $\begin{array}{r}\text { Changing } \\
\text { fertilizer }\end{array}$ & Irrigation & $\begin{array}{r}\text { Crop } \\
\text { diversification }\end{array}$ \\
\hline Intercept & $-5.0048^{*}$ & $-1.2789^{* *}$ & $-3.1395^{*}$ & $-4.9009^{*}$ & $-6.9262 *$ & $-4.845^{*}$ & $-5.587^{*}$ & $-3.826^{*}$ \\
\hline Farm experience (years) & 0.0065 & $0.0316^{*}$ & $0.0350^{*}$ & -0.0029 & 0.0217 & $3.314^{*}$ & 0.018 & 0.002 \\
\hline Years of education & $0.1336^{*}$ & $0.0618^{* *}$ & $0.1229^{*}$ & $0.0641^{* *}$ & $0.1395^{*}$ & $1.397^{*}$ & $0.142^{*}$ & 0.038 \\
\hline Household size & 0.0316 & -0.0365 & 0.0141 & $0.1102^{*}$ & $0.0644^{* *}$ & 2.469 & -0.002 & -0.007 \\
\hline Land area (acres) & $0.0093^{* *}$ & $0.0200^{*}$ & 0.0026 & -0.0048 & -0.0020 & -1.679 & 0.003 & 0.006 \\
\hline Tenancy status owner (base tenant) & $-1.2338^{*}$ & -0.4066 & $-0.6840^{*}$ & -0.0057 & -0.5095 & $-7.371^{* *}$ & -0.565 & -0.322 \\
\hline Tube well ownership & $0.9512^{* *}$ & -0.1819 & 0.0511 & 0.2835 & 0.4408 & $7.316^{* *}$ & 0.405 & 0.213 \\
\hline Distance from the local market & $-0.0773^{* *}$ & -0.0156 & -0.0104 & 0.0163 & -0.0378 & -6.844 & -0.051 & -0.063 \\
\hline Access to farm credit & -0.1793 & 0.0876 & -0.0924 & -0.4597 & -0.0478 & -1.736 & 0.247 & -0.192 \\
\hline Access to information on water delivery & -0.7165 & 0.5820 & $0.6729^{* *}$ & -0.1998 & 0.2123 & 5.549 & -0.210 & 0.158 \\
\hline Information on weather forecasting & $1.5052^{* *}$ & -0.2564 & $0.8692^{* *}$ & $2.5448^{*}$ & $2.2544^{* *}$ & $1.279^{* *}$ & $2.207^{* *}$ & $1.255^{* *}$ \\
\hline Agricultural extension services provided for crop and livestock production & $-0.8448^{* *}$ & $0.6958^{* *}$ & 0.2537 & 0.2829 & -0.3809 & -1.976 & -0.536 & -0.642 \\
\hline Access to market information & $1.1377^{* *}$ & 0.1153 & -0.0616 & 0.0088 & 0.1759 & 9.942 & 0.161 & 0.165 \\
\hline Mixed crop zone (base rain-fed zone) & -0.7351 & $-0.5965^{* *}$ & $-1.4044^{*}$ & $-0.7664^{* *}$ & -0.6644 & $-1.008^{* *}$ & -0.696 & -0.954 \\
\hline Cotton zone (base rain-fed zone) & $1.0392^{* *}$ & $-1.5353^{*}$ & $-0.5562^{* *}$ & -0.1057 & $0.9810^{* *}$ & -3.330 & $0.901^{* *}$ & $1.058^{* *}$ \\
\hline$N$ & 450 & 450 & 450 & 450 & 450 & 450 & 450 & 450 \\
\hline
\end{tabular}

*, ${ }^{* *}$ Significant at 1 and $5 \%$ probability levels, respectively

Table 5. Marginal effects from the binary logistic models of farm-level adaptation measures.

\begin{tabular}{|c|c|c|c|c|c|c|c|c|}
\hline Explanatory variables & $\begin{array}{r}\text { Changing } \\
\text { crop } \\
\text { type }\end{array}$ & $\begin{array}{r}\text { Changing } \\
\text { crop } \\
\text { variety }\end{array}$ & $\begin{array}{r}\text { Changing } \\
\text { planting } \\
\text { dates }\end{array}$ & $\begin{array}{r}\text { Planting } \\
\text { shade } \\
\text { trees }\end{array}$ & $\begin{array}{r}\text { Soil } \\
\text { conservation }\end{array}$ & $\begin{array}{l}\text { Changing } \\
\text { fertilizer }\end{array}$ & Irrigation & $\begin{array}{r}\text { Crop } \\
\text { diversification }\end{array}$ \\
\hline Farm experience (years) & 0.0005 & 0.0059 & 0.0061 & -0.0005 & 0.0016 & 0.0044 & 0.0014 & 0.0001 \\
\hline Years of education & 0.0101 & 0.0116 & 0.0214 & 0.0104 & 0.0101 & 0.0185 & 0.0112 & 0.0025 \\
\hline Household size (individuals) & 0.0024 & -0.0069 & 0.0025 & 0.0179 & 0.0047 & 0.0033 & -0.0001 & -0.0004 \\
\hline Land area (acres) & 0.0007 & 0.0038 & 0.0005 & -0.0008 & 0.0001 & 0.0000 & 0.0002 & 0.0004 \\
\hline Tenancy status owner (base tenant) & -0.0929 & -0.0764 & -0.1192 & -0.0009 & -0.0369 & -0.0977 & -0.0448 & -0.0210 \\
\hline Tube well ownership & 0.0716 & -0.0342 & 0.0089 & 0.0460 & 0.0319 & 0.0969 & 0.0321 & 0.0139 \\
\hline Distance from the local market & -0.0058 & -0.0029 & -0.0018 & 0.0026 & -0.0027 & -0.0009 & -0.0041 & -0.0041 \\
\hline Access to farm credit & -0.0135 & 0.0165 & -0.0161 & -0.0747 & -0.0035 & -0.0230 & 0.0196 & -0.0125 \\
\hline Access to information on water delivery & -0.0539 & 0.1093 & 0.1173 & -0.0324 & 0.0154 & 0.0735 & -0.0166 & 0.0103 \\
\hline Information on weather forecasting & 0.1133 & -0.0482 & 0.1515 & 0.4133 & 0.1633 & 0.1695 & 0.1750 & 0.0817 \\
\hline Agricultural extension services provided for crop and livestock production & -0.0636 & 0.1307 & 0.0442 & 0.0459 & -0.0276 & -0.0262 & -0.0425 & -0.0418 \\
\hline Access to market information & 0.0856 & 0.0217 & -0.0107 & 0.0014 & 0.0127 & 0.0132 & 0.0128 & 0.0108 \\
\hline Irrigated plains mixed crop zone (base rain-fed zone) & -0.0553 & -0.1121 & -0.2447 & -0.1245 & -0.0481 & -0.1335 & -0.0552 & -0.0621 \\
\hline Irrigated plains cotton zone (base rain-fed zone) & 0.0782 & -0.2885 & -0.0969 & -0.0172 & 0.0710 & -0.0441 & 0.0715 & 0.0689 \\
\hline$N$ & 450 & 450 & 450 & 450 & 450 & 450 & 450 & 450 \\
\hline
\end{tabular}

\subsubsection{Tube well ownership}

Tube well ownership indicates adequate supply of ground water for crops in time of need. The ownership of a tube well is positively associated with the majority of the adaptation measures, even though the coefficients are insignificant (Table 4). Moreover, ownership of a tube well leads to $7.16 \%$ increase in the likelihood of adopting changing crop type and $9.69 \%$ increase in the probability of changing fertilizer (Table 5). Hence, it can be concluded that farmers with a tube well are more likely to adapt their agriculture to climate change as they have the assurance of sufficient water supply to make any adjustment at the farm level in response to variability in climate.

\subsubsection{Distance from the local market}

Proximity to market may serve as a means of sharing and exchanging information with farmers and other service providers (Maddison, 2007). In this study for most of the adaptation measures, the coefficient of distance from the local market is negative which indicates that farmers located near to the local market have more chances to adapt to climate change compared to farmers who are far away from the market (Table 4). A $1 \%$ increase in the distance of the farm from nearest local market results in a decrease of $0.05 \%$ in the probability of the changing crop type (Table 6).

\subsubsection{Access to farm credit}

Access to farm credit has an insignificant effect on the adaptation to climate change. Access to farm credit is positively related to changing crop variety and increased irrigation and negatively related to the changing crop type, changing planting dates, planting shade trees, soil conservation, changing fertilizer and crop diversification, although not significantly (Table 4).

\subsubsection{Access to information on water delivery}

Access to information on water delivery has a positive but insignificant impact on most of the adaptation measures except changing planting dates (Table 4). The access to information on water delivery increases the likelihood of changing plant- 
Table 6. Elasticity calculations of the binary logistic models of farm-level adaptation measures.

\begin{tabular}{|c|c|c|c|c|c|c|c|c|}
\hline Explanatory variables & $\begin{array}{r}\text { Changing } \\
\text { crop } \\
\text { type }\end{array}$ & $\begin{array}{r}\text { Changing } \\
\text { crop } \\
\text { variety }\end{array}$ & $\begin{array}{r}\text { Changing } \\
\text { planting } \\
\text { dates }\end{array}$ & $\begin{array}{r}\text { Planting } \\
\text { shade } \\
\text { trees }\end{array}$ & $\begin{array}{r}\text { Soil } \\
\text { conservation }\end{array}$ & $\begin{array}{c}\text { Changing } \\
\text { fertilizer }\end{array}$ & Irrigation & $\begin{array}{r}\text { Crop } \\
\text { diversification }\end{array}$ \\
\hline Farm experience (years) & 0.0119 & 0.1445 & 0.1487 & -0.0114 & 0.0383 & 0.1070 & 0.0348 & 0.0026 \\
\hline Years of education & 0.0817 & 0.0942 & 0.1739 & 0.0845 & 0.0821 & 0.1503 & 0.0911 & 0.0203 \\
\hline Household size (individuals) & 0.0230 & -0.0662 & 0.0238 & 0.1729 & 0.0450 & 0.0316 & -0.0014 & -0.0041 \\
\hline Land area (acres) & 0.0113 & 0.0604 & 0.0074 & -0.0124 & 0.0023 & 0.0000 & 0.0032 & 0.0062 \\
\hline Tenancy status owner (base tenant) & -0.0752 & -0.0619 & -0.0965 & -0.0008 & -0.0299 & -0.0791 & -0.0363 & -0.0170 \\
\hline Tube well ownership & 0.0451 & -0.0215 & 0.0056 & 0.0290 & 0.0201 & 0.0611 & 0.0202 & 0.0088 \\
\hline Distance from local market & -0.0529 & -0.0267 & -0.0164 & 0.0241 & -0.0249 & -0.0082 & -0.0371 & -0.0374 \\
\hline Access to farm credit & -0.0043 & 0.0053 & -0.0052 & -0.0239 & -0.0011 & -0.0074 & 0.0063 & -0.0040 \\
\hline Access to information on water delivery & -0.0421 & 0.0853 & 0.0915 & -0.0253 & 0.0120 & 0.0574 & -0.0130 & 0.0080 \\
\hline Information on weather forecasting & 0.0952 & -0.0405 & 0.1272 & 0.3472 & 0.1371 & 0.1424 & 0.1470 & 0.0687 \\
\hline Agricultural extension services provided for crop and livestock production & -0.0273 & 0.0562 & 0.0190 & 0.0198 & -0.0119 & -0.0113 & -0.0183 & -0.0180 \\
\hline Access to market information & 0.0651 & 0.0165 & -0.0082 & 0.0011 & 0.0097 & 0.0100 & 0.0097 & 0.0082 \\
\hline Irrigated plains mixed crop zone (base rain-fed zone) & -0.0183 & -0.0370 & -0.0808 & -0.0411 & -0.0159 & -0.0441 & -0.0182 & -0.0205 \\
\hline Irrigated plains cotton zone (base rain-fed zone) & 0.0258 & -0.0952 & -0.0320 & -0.0057 & 0.0234 & -0.0146 & 0.0236 & 0.0227 \\
\hline
\end{tabular}

ing dates by $11.73 \%$ (Table 5). We can conclude that farmers who have more access to information on water delivery are more likely to adjust the planting dates according to water availability.

\subsubsection{Information on weather forecasting}

Information on seasonal and daily weather forecasting (i.e., temperature and rainfall) has a positive and significant effect on the probability of changing crop types, changing planting dates, planting shade trees, soil conservation, changing fertilizer, irrigation and crop diversification as adaptation methods (Table 4). The results in Table 5 show that access to information on seasonal and daily weather increases the probability of planting shade trees $(41.33 \%)$, increased irrigation $(17.50 \%)$, changing fertilizers $(16.95 \%)$, soil conservation $(16.33 \%)$, changing planting dates $(15.15 \%)$, changing crop type (11.33\%) and crop diversification (8.17\%). In summary, the information on weather forecasting increases the likelihood of adaptation to climate change.

\subsubsection{Agricultural extension services provided for crop and livestock production}

The provision of agricultural extension services is an ongoing process and can be defined as a systematic tool of dissemination of useful and practical information related to agriculture, including improved farm inputs, farming techniques and skills to farmers or rural communities with the objective of improving their farm production and income (Syngenta, 2014; Swanson and Claar, 1984).

The results in Table 4 indicate that provision of extension services for crop production is significantly and positively related to changing crop variety. On the other hand, it is significantly and negatively related to the probability of changing crop type which may be due to the reason that farmers get poor information on crop production and adaptation to climate change, or the information from the extension services is outdated. The results of the marginal effect in Table 5 show that access to extension services leads to $13.07 \%$ increase in the likelihood of changing crop variety and decrease of $6.36 \%$ in the likelihood of changing crop type as an adaptation method. For all other adaptation measures, no significant relationship is found between extension and adaptation measures. These results support the farmers' complaints about the lack of updated information on adaptation to climate change from the agricultural extension department.

\subsubsection{Access to market information}

The results of logistic regression show a positive association between access to market information and the adaptation to climate change though most of the coefficients are insignificant (Table 4). The probability of changing crop type increases by $8.56 \%$ if farmers have access to market information (Table 5).

\subsubsection{Irrigated plains mixed crop zone (base rain-fed zone)}

Farmers living in different agroecological zones used different adaptation measures. For example, farming in mixed crop zones leads to an increase in the likelihood of changing crop variety $(11.21 \%)$, changing planting dates $(24.47 \%)$, planting shade trees $(12.45 \%)$ and changing fertilizers $(13.35 \%)$ compared to the farming in the cotton zone or rain-fed zone (Table 5). From the results, we can conclude that farmers in different crop zones adapt differently based on crop patterns and needs.

\subsubsection{Irrigated plains cotton zone (base rain-fed zone)}

Likelihood of changing crop type (7.82\%), soil conservation $(7.10 \%)$, irrigation $(7.15 \%)$ and crop diversification $(6.89 \%)$ increases in the case of farming in the cotton zone (Rahim Yar Khan) compared to the farming in other zones. Moreover, farming in the cotton zone reduces the probability of changing crop varieties and changing planting dates as adaptation methods by 28.85 and $9.69 \%$, respectively, compared to the farming in other zones (Table 5). 


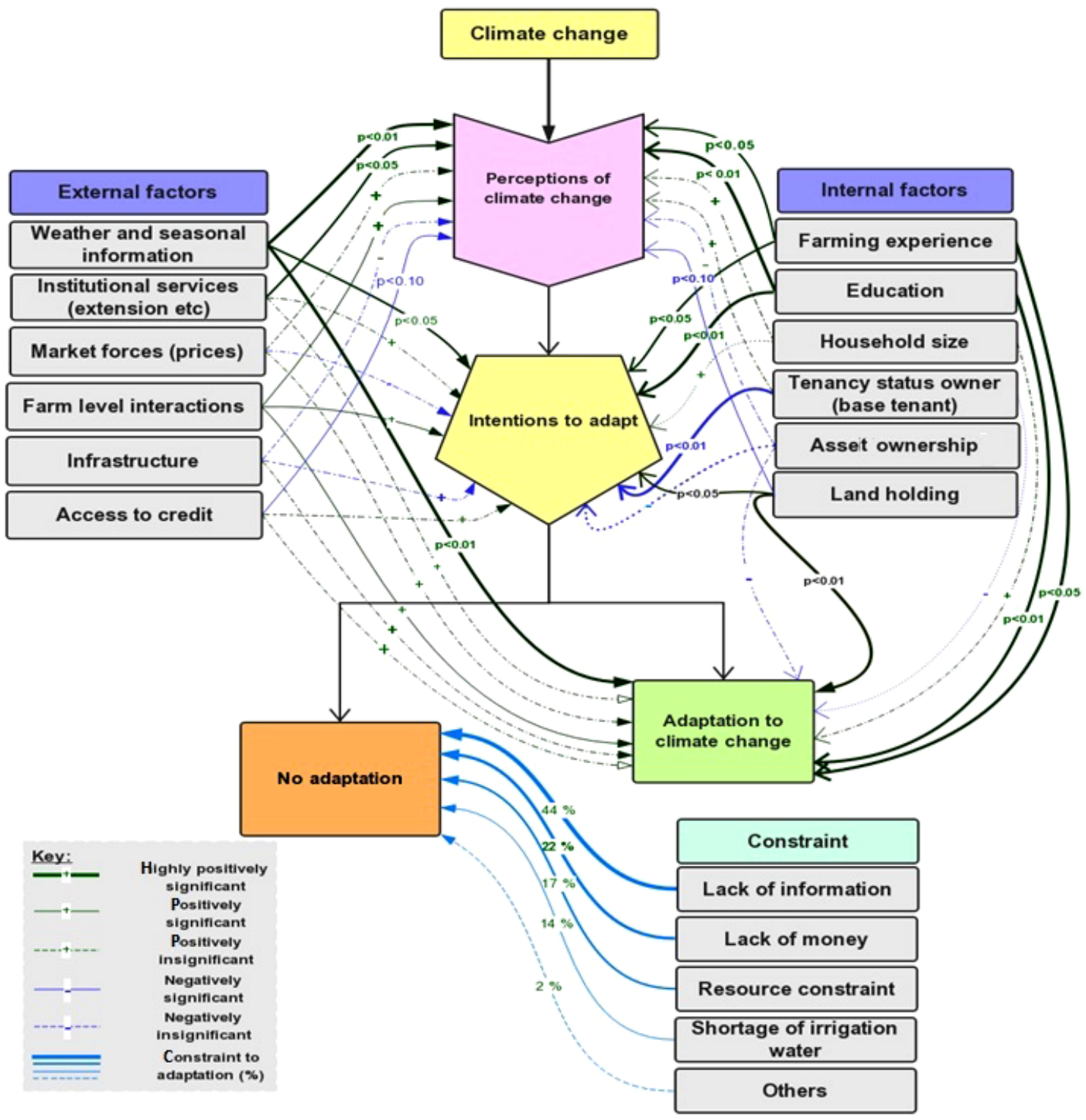

Figure 9. Schematic framework of farmers' adaptation process in Pakistan (own illustration).

\subsection{Schematic framework of farmers' adaptation process}

A schematic framework of the farmers' adaptation process was developed based on field data analysis to summarize the adaptation process at the farm level (Fig. 9). In this framework, we described the farmers' adaptation process as a three-step procedure. In the first step, farm households perceive climate change and its adverse impacts on their agricultural production. These perceptions can be defined through various internal (socioeconomic) and external (e.g., environmental or institutional) factors. In the second stage, farmers showed their intentions to adopt certain measures to adapt to climate change that again can be described or influenced by internal and external factors mentioned in Sect. 2.1. In the last and third stage, farmers decide either to adapt or not to perceived changes in climate. Farmers' adoption of particular adaptation measures again may be subject to various internal and external factors (Table 4), while the farmers' decision to not adapt to climate variability may be explained by various constraints elaborated by the farmers, including those who did not adapt even with intentions (Fig. 2). In this framework, the width of connection lines shows the significance or insignificance of individual variables on the perceptions, intentions or adaptations. Green and blue lines represent positive and negative relations between interdependent variables (perceptions, intentions or adaptations), respectively, while dotted lines represent a weak link, and solid lines show a significant relationship. 


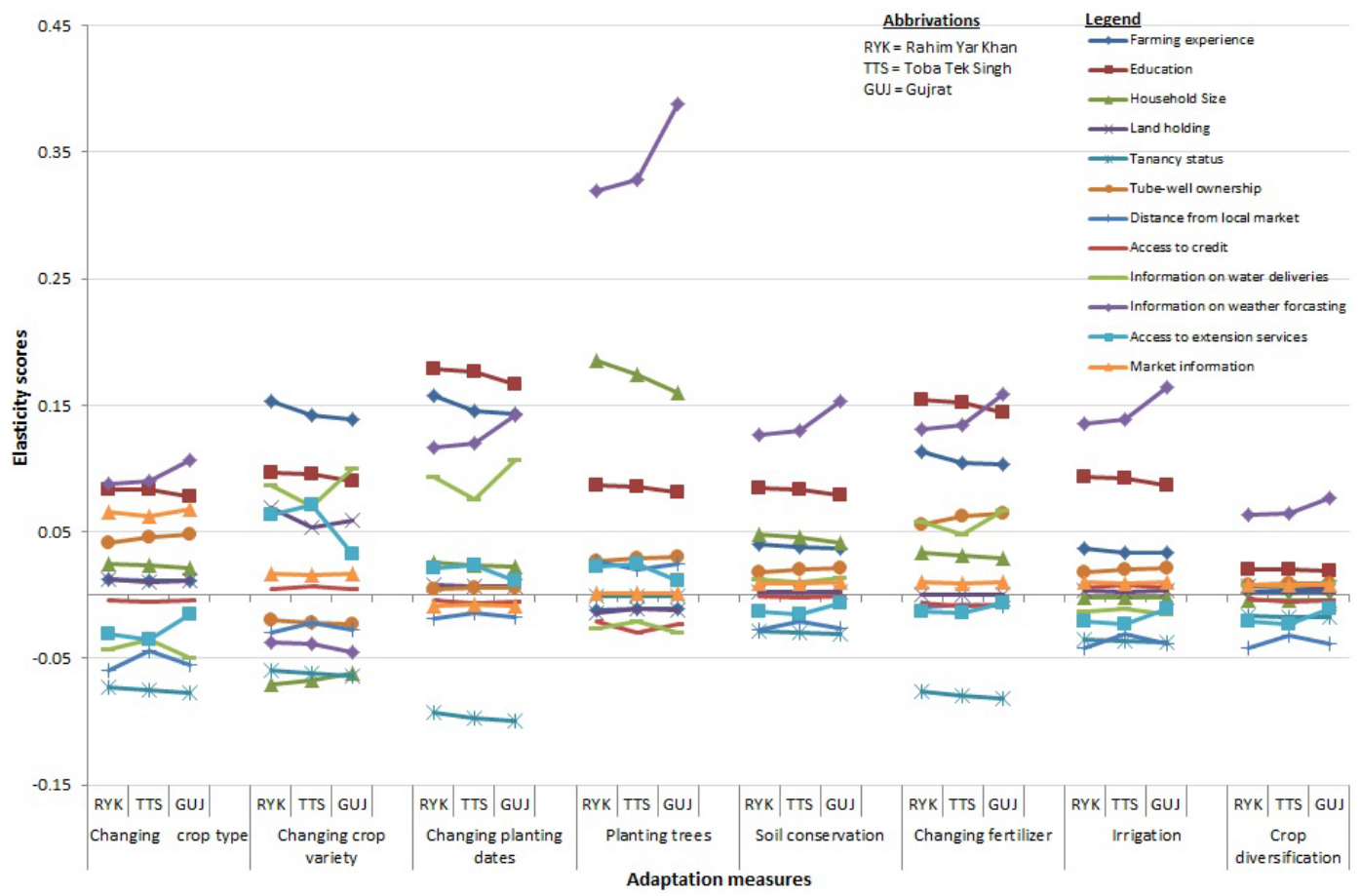

Figure 10. Partial elasticity calculations across three study districts of Punjab province.

\subsection{Partial elasticity comparisons across regions}

We further analyzed and compared the partial elasticities of explanatory variables for all adaptation methods across three study districts (Fig. 10). From the results, it can be observed that elasticity scores range from -0.01 to 0.20 except for the elasticity scores of the weather information variable $(0.30$ 0.40) of the planting shade trees model. Elasticity of farming experiences is higher for farmers in the Rahim Yar Khan district for most of the adaptation methods followed by farmers in Toba Tek Singh district and Gujrat. The highest elasticity for farming experience was observed in the case of adaptation measures changing crop varieties (0.15) and changing planting dates (0.16) in Rahim Yar Khan, which indicates that farming experience increases the chances of adaptation to climate change in Rahim Yar Khan more compared to the districts of Toba Tek Singh and Gujrat. The same trend was found for elasticity of education where the highest score (0.18) was obtained for changing planting dates in Rahim Yar Khan and the lowest elasticity score was found for crop diversification (0.02) in Gujrat. It can be concluded that education has more significant effects on adaptation to climate change in the Rahim Yar Khan district.

Elasticity calculations for household size show the highest elasticity in the case of planting shade trees in Rahim Yar Khan (0.19) while the lowest elasticity of household size (but insignificant) was observed for changing crop variety $(-0.07)$ for the Rahim Yar Khan district. Elasticities of household size were close to zero for the irrigation and crop diversification method of adaptation. In the case of the variable of total landholding, the highest coefficient was observed for changing crop variety in Rahim Yar Khan district (0.07) while for adaptation methods soil conservation, changing fertilizer, irrigation and crop diversification, the coefficient was close to zero, which indicates little or no effect of landholding on adoption of these measures. Elasticity coefficients for the tenancy status variable were the highest for Rahim Yar Khan district followed by Toba Tek Singh and Gujrat.

\section{Conclusions and policy suggestions}

Climate change is a reality which is expected to have significant impacts on Pakistan's economy with an increase in the frequency of extreme events including floods and droughts and changing rainfall patterns (Asif, 2013). Being severely dependent on natural water resources, agriculture in Pakistan is particularly vulnerable to further climate change. Hence, suitable adaptation measures to climate change are important. This study uses novel farm-level data from three distinct agroecological zones in Pakistan to analyze farmers' awareness and their adaptive capacities and measures to changes in climate.

This study reveals real and perceived constraints for farmlevel adaptation to climate change. Most constraints are institutional in nature and can be covered with improving the institutional services in terms of access, use and viability for climate adaptation. Furthermore, this study shows the impor- 
tance of different types of institutional services such as easy access to information on weather forecasting and improved agricultural technologies; easy access to resources and financial services for the enhancement of farm-level adaptation. However, the services currently provided at the farm level are not sufficient to support an effective adaptation process. Hence there is dire need for collaboration at different levels of the adaptation process. This could consist of publicprivate partnerships or integration at horizontal and vertical levels across public and private organizations. This study also shows that farmers in different agroecological zones prefer different adaptation measures. This diversity confirms the need for research at local levels, i.e., in different agroecological zones, to develop efficient and effective adaptation strategies for the agriculture sector.
The study also shows that historical adaptation measures at the farm level do generally not include advanced management technologies but are limited to simple measures, particularly changing crops or crop varieties. Very few farmers adopted advanced adaptation measures. As we already mentioned, the reason behind not using advanced measures lies in lack of knowledge and support from local institutions. Hence, future policies need to address barriers for the adoption of advanced adaptation measures at the farm level such as providing information and support, introducing climate smart varieties, promoting soil conservation and new adaptation measures based on different agroecological zones. Despite the need for locally specific adaptation of agriculture to climate change, investment and research are also needed at the macro level. In particular, commodity prices, resource endowments, and environmental impacts depend on regional and international developments but interact with local adaptation measures. 
Appendix A: Marginal effect and elasticity calculations

Assume a logit function (in terms of observed variable $Y_{i j}$ ) already explained in Eq. (3) in Sect. 2:

$\operatorname{Pr}\left(Y_{i j}=1\right)=Y_{i j}=G\left(X_{k} \beta\right)$,

where $G($.$) takes the specific binomial distribution (Ferni-$ hough, 2011).

If we take the partial derivative of Eq. (3) with respect to explanatory variable $X_{k}$, by applying chain rule (Dawkins, 2005), it will give us the marginal effect as follows:

$$
\begin{aligned}
\frac{\partial Y_{i j}}{\partial X_{k}} & =\frac{\partial G\left(X_{k} \beta\right)}{\partial X_{k}}=\frac{\partial G\left(X_{k} \beta\right)}{\partial X_{k} \beta} \cdot \frac{\partial X_{k} \beta}{\partial X_{k}} \\
& =G^{\prime}\left(X_{k} \beta\right) \cdot \beta_{k}=g\left(X_{k} \beta\right) \beta_{k} .
\end{aligned}
$$

As we know that

$G\left(X_{k} \beta\right)=\frac{e^{X_{k} \beta}}{1+e^{X_{k} \beta}}$,

the derivative of $G\left(X_{k} \beta\right)$ with respect to $X_{k} \beta$ by applying the quotient rule (Dawkins, 2005) will be as follows:

$$
\begin{aligned}
g\left(X_{k} \beta\right) & =\frac{\left(1+e^{X_{k} \beta}\right) \cdot e^{X_{k} \beta}-e^{X_{k} \beta} \cdot e^{X_{k} \beta}}{\left(1+e^{\left(X_{k} \beta\right)}\right)^{2}} \\
& =\frac{e^{\left(X_{k} \beta\right)}}{\left(1+e^{X_{k} \beta}\right)^{2}} .
\end{aligned}
$$

If we put the value of $g\left(X_{k} \beta\right)$ from Eq. (A3) into Eq. (A2) then it becomes

$$
\frac{\partial Y_{i j}}{\partial X_{k}}=\frac{e^{\left(X_{k} \beta\right)}}{\left(1+e^{X_{k} \beta}\right)^{2}} \cdot \beta_{k} .
$$

Usually marginal effects are calculated at mean of explanatory variables $\left(\overline{X_{k}}\right)$ so we may replace $X_{k}$ with mean value of $\overline{X_{k}}$ (Schmidheiny, 2013):

$$
\begin{aligned}
& y_{i j}^{\prime}=\frac{e^{\left(\overline{X_{k}} \beta\right)}}{1+e^{\left(\overline{X_{k}} \beta\right)}} \cdot \frac{1}{1+e^{\left(\overline{X_{k}} \beta\right)}} \cdot \beta_{k}, \\
& =\operatorname{Pr}\left(Y_{i j}=1\right) \cdot\left(1-\frac{e^{\left(\overline{X_{k}} \beta\right)}}{1+e^{\left(\overline{X_{k}} \beta\right)}}\right) \cdot \beta_{k}, \\
& =\operatorname{Pr}\left(Y_{i j}=1\right) \cdot\left(1-\operatorname{Pr}\left(Y_{i j}=1\right)\right) \cdot \beta_{k} .
\end{aligned}
$$

Partial elasticity can be easily calculated from marginal effects. As we already know, elasticity is the responsiveness of the dependent variable in percentage given a percentage change in the independent variable. However, the elasticity measure for logistic regression is different from other normal elasticity measures because, in the case of logistic regression, the dependent variable is a unitless number and takes values between 0 and 1 (Curran, 2010). Hence partial elasticity $\left(\eta_{Y}\right)$ for logistic regression may be defined as

$\eta_{Y}\left(X_{k}\right)=X_{k} \cdot \frac{\partial G\left(X_{k} \beta\right)}{\partial X_{k}}$.

As $\frac{\partial G\left(X_{k} \beta\right)}{\partial X_{k}}$ is simply the marginal effect of logistic regression (see Eq. A4) so we may write Eq. (A5) as

$\eta_{Y}\left(X_{k}\right)=X_{k} \cdot \operatorname{Pr}\left(Y_{i j}=1\right) \cdot\left(1-\operatorname{Pr}\left(Y_{i j}=1\right)\right) \beta_{k}$.

Moreover, we can conclude that partial elasticity is equal to $X_{k}$ times the marginal effect $\left(y_{i j}^{\prime}\right)$ (Rahji and Fakayode, 2009).

In a similar way of calculating marginal effects, partial elasticities are also calculated at mean of explanatory variables $\left(\overline{X_{k}}\right)$, and thus we may write Eq. (A6) as

$\eta_{Y}\left(\overline{X_{k}}\right)=\beta_{k} \overline{X_{k}} \operatorname{Pr}\left(Y_{i j}=1\right)\left(1-\operatorname{Pr}\left(Y_{i j}=1\right)\right)$,

where

$\operatorname{Pr}\left(Y_{i j}=1\right)=\frac{e^{\left(\overline{X_{k}} \beta\right)}}{1+e^{\left(\overline{X_{k}} \beta\right)}}$. 
Acknowledgements. This study is part of a $\mathrm{PhD}$ research at the School of Integrated Climate System Sciences (SICSS), University of Hamburg, Germany. This $\mathrm{PhD}$ research is made possible under the sponsor of Higher Education Commission (HEC), Pakistan; Deutscher Akademischer Austauschdienst (DAAD); Kompetenzzentrum Nachhaltige Universität (KNU) and the Research Group Climate Change and Security (CLISEC) in the Integrated Climate System Analysis and Prediction (CliSAP) Cluster of Excellence supported by Deutsche Forschungsgemeinschaft (DFG). We are very thankful to the Department of Agriculture (Extension wing) Punjab, local farmer representatives for their effective coordination and support in organizing and conducting successful farmer interviews. Further, we would like to thank our survey team members, Muhammad Usman, Muhammad Haseeb Rizwi and Muhammad Ikhlaq Mansoor and farm households in Punjab in helping and supporting our interviews during March and April 2014.

Edited by: V. Lucarini

\section{References}

Abid, M., Ashfaq, M., Khalid, I., and Ishaq, U.: An economic evaluation of impact of soil quality on Bt (Bacillus thuringiensis) cotton productivity, Soil Environ., 30, 78-81, 2011a.

Abid, M., Ashfaq, M., Hassan, S., and Fatima, N.: A resource use efficiency analysis of small Bt cotton farmers in Punjab, Pakistan, Pak. J. Agric. Sci., 48, 65-71, 2011 b.

Adger, W. N., Dessai, S., Goulden, M., Hulme, M., Lorenzoni, I., Nelson, D. R., Naess, L. O., Wolf, J., and Wreford, A.: Are there social limits to adaptation to climate change?, Climatic Change, 93, 335-354, 2009.

Ahmed, H., Khan, M. R., Panadero-Fontan, R., Lopez-Sández, C., Iqbal, M. F., Naqvi, S. M. S., and Qayyum, M.: Geographical distribution of hypodermosis (Hypoderma sp.) in northern Punjab, Pakistan, Kafkas Univ Vet Fak Derg, 18, A215-A219, 2012.

Ashfaq, M., Zulfiqar, F., Sarwar, I., Quddus, M. A., and Baig, I. A.: Impact of climate change on wheat productivity in mixed cropping system of Punjab, Soil Environ., 30, 110-114, 2011.

Asif, M.: Climatic Change, Irrigation Water Crisis and Food Security in Pakistan, No. 170, Master thesis in sustainable development at Uppsala University, Uppsala, 39 pp., 2013.

Badar, H., Ghafoor, A., and Adil, S. A.: Factors affecting agricultural production of Punjab (Pakistan), Pak. J. Agri. Sci, 44, 3, 2007.

Bryan, E., Ringler, C., Okoba, B., Roncoli, C., Silvestri, S., and Herrero, M.: Adapting agriculture to climate change in Kenya: Household strategies and determinants, J. Environ. Manage., 114, 26-35, 2013.

Croppenstedt, A., Demeke, M., and Meschi, M. M.: Technology adoption in the presence of constraints: the case of fertilizer demand in Ethiopia, Rev. Develop. Econ., 7, 58-70, 2003.

Curran, C.: Logit and Probit Regressions, available online at: http: //cnx.org/contents/7cafdabf-7ed1-4a02-b40a-e4c9598f9709@3 (last acces: 22 July 2014), 2010.

Dawkins, P.: Derivatives definitions and notation, available at: http://tutorial.math.lamar.edu/pdf/Calculus_ CheatSheetDerivatives_Reduced.pdf (last acces: 29 August 2014), 2005.
Deressa, T. T.: Measuring the economic impact of climate change on Ethiopian agriculture: Ricardian approach, World Bank Policy Research Paper No. 4342, World Bank, Washington, D.C., 2007.

Deressa, T. T., Hassan, R. M., Ringler, C., Alemu, T., and Yesuf, M.: Determinants of farmers' choice of adaptation methods to climate change in the Nile Basin of Ethiopia, Global Environ. Change, 19, 248-255, 2009.

Deressa, T. T., Hassan, R. M., and Ringler, C.: Perception of and adaptation to climate change by farmers in the Nile basin of Ethiopia, J. Agric. Sci., 149, 23-31, 2011.

Elahi, E., Zhang, L., Abid, M., Altangerel, O., Bakhsh, K., Uyanga, B., Ahmed, U. I., and Xinru, H.: Impact of Balance Use of Fertilizers on Wheat Efficiency in Cotton Wheat Cropping System of Pakistan, Int. J. Agric. Innov. Res. 3, 1470-1474, 2015.

Farooq, O.: Chapter Agriculture, in Pakistan Economic survey 2012-13, Ministry of Finance, Government of Pakistan, Islamabad, 2013.

Farooqi, A. B., Khan, A. H., and Mir, H.: Climate change perspective in Pakistan, Pakistan J. Meteorol., 2, 11-21, 2005.

Fernihough, A.: Simple logit and probit marginal effects in R, Working paper series, UCD Center for economic research, University of Dublin, Ireland, 2011.

Government of Pakistan: Pakistan Mouza statistics, Statistics Division, Agricultural Census Organization, Islamabad, Pakistan, 1998.

Hanif, U., Syed, S. H., Ahmad, R., Malik, K. A., and Nasir, M.: Economic Impact of Climate Change on the Agricultural Sector of Punjab, Pakistan Develop. Rev., 49, 771-798, 2010.

Hassan, R. and Nhemachena, C.: Determinants of African farmers' strategies for adapting to climate change: Multinomial choice analysis, Afr. J. Agric. Resour. Econ., 2, 83-104, 2008.

Hijioka, Y., Lin, E., Pereira, J. J., Corlett, R. T., Cui, X., Insarov, G. E., Lasco, R. D., Lindgren, E., and Surjan, A.: Asia, in: Climate Change 2014: Impacts, Adaptation, and Vulnerability, Part B: Regional Aspects. Contribution of Working Group II to the Fifth Assessment Report of the Intergovernmental Panel on Climate Change, edited by: Barros, V. R., Field, C. B., Dokken, D. J., Mastrandrea, M. D., Mach, K. J., Bilir, T. E., Chatterjee, M., Ebi, K. L., Estrada, Y. O., Genova, R. C., Girma, B., Kissel, E. S., Levy, A. N., MacCracken, S., Mastrandrea, P. R., and White, L. L., Cambridge University Press, Cambridge, UK and New York, NY, USA, 2014.

Hisali, E., Birungi, P., and Buyinza, F.: Adaptation to climate change in Uganda: evidence from micro level data, Global Environ. Change, 21, 1245-1261, 2011.

Hosmer Jr., D. W. and Lemeshow, S.: Applied logistic regression, John Wiley \& Sons, New York, 2004.

Hussain, S. S. and Mudasser, M.: Prospects for wheat production under changing climate in mountain areas of Pakistan. An econometric analysis, Agricult. Syst., 94, 494-501, 2007.

IFAD.: Climate change impacts, South Asia, httP://www.ifad.org/ events/apr09/impact/seasia.pdf (last acces: 12 July 2014), 2010.

IPCC - Intergovernmental Panel on Climate Change: Climate Change 2001: Impacts, Adaptation and Vulnerability, contribution of working group II to the Third Assessment Report of the IPCC, Cambridge University Press, Cambridge, 2001.

IUCN.: Climate change; vulnerabilities in agriculture in Pakistan, http://cmsdata.iucn.org/downloads/pkcc_agrvul.pdf (last acces: 18 August 2014), 2009. 
Kato, E., Ringler, C., Yesuf, M., and Bryan, E.: Soil and water conservation technologies: a buffer against production risk in the face of climate change? Insights from the Nile basin in Ethiopia, Agric. Econ., 42, 593-604, 2011.

Kreft, S. and Eckstein, D.: Global Climate Risk Index 2014: Who Suffers Most from Extreme Weather Events? Weather-Related Loss Events in 2012 and 1993 to 2012, Germanwatch eV, Bonn, Germany, 2013.

LP - Leads Pakistan: LEAD climate change action program, Internal Document, LEAD Pakistan, Islamabad, 2010.

Maddison, D.: The perception of and adaptation to climate change in Africa, World Bank Policy Research Working Paper, Wold Bank, Washington DC, 2007.

Mertz, O., Mbow, C., Reenberg, A., and Diouf, A.: Farmers' perceptions of climate change and agricultural adaptation strategies in rural Sahel, Environ. Manage. 43, 804-816, 2009.

Mohammad, S.: Supply Response of Major Crops in Different Agro-Ecologic Zones in Punjab, Ph.D., University of Agriculture, Faisalabad, unpublished thesis, 2005.

Nhemachena, C. and Hassan, R.: Micro-level analysis of farmers' adaption to climate change in Southern Africa, Intl. Food Policy Res. Inst., Washington, DC, 2007.

Nomman, M. A. and Schmitz, M.: Economic assessment of the impact of climate change on the agriculture of Pakistan, Business Econ. Horiz., 4, 1-12, 2011.

Norris, P. E. and Batie, S. S.: Virginia farmers, soil conservation decisions: an application of Tobit analysis, S. J. Agric. Econ., 19, 79-90, 1987.

Organisation for Economic Co-operation and Development OECD.: The Economics of Adapting Fisheries to Climate Change, OECD Publishing, Chateau de la Muette, Paris, France, doi:10.1787/9789264090415-en, 2011.

PARC - Pakistan Agricultural Research Council: National Master Agricultural Research Plan, PARC, available at: http://old. parc.gov.pk/Maps/AgroEcoPunjab.html (last access: 21 August 2014), 2014.

Parry, M. L.: Climate Change 2007: impacts, adaptation and vulnerability: contribution of Working Group II to the fourth assessment report of the Intergovernmental Panel on Climate Change, Cambridge University Press, 2007.
PBS - Pakistan Bureau of Statistics: Agricultural statistics of Pakistan. Government of Pakistan, statistics division, Pakistan bureau of statistics, available at: http://www.pbs.gov.pk/content/ agricultural-statistics-pakistan-2010-11 (last access: 1 August 2014), 2011.

Peng, C. Y. J., Lee, K. L., and Ingersoll, G. M.: An introduction to logistic regression analysis and reporting, J. Educat. Res., 96, 3-14, 2002.

Rahji, M. and Fakayode, S.: A multinomial logit analysis of agricultural credit rationing by commercial banks in Nigeria, Int. Res. J. Finance Econ., 24, 97-103, 2009.

Schlenker, W. and Lobell, D. B.: Robust negative impacts of climate change on African agriculture, Environm. Res. Lett., 5, 014010, doi:10.1088/1748-9326/5/1/014010, 2010.

Schmidheiny, K.: Binary Response Models, Short guides to Microeconometrics, Unversität Basel, Basel, 2013.

Stephenson, B., Cook, D., Dixon, P., Duckworth, W., Kaiser, M., Koehler, K., and Meeker, W.: Binary response and logistic regression analysis, available at: http://www.stat.wisc.edu/ $\sim$ mchung/teaching/MIA/reading/GLM.logistic.Rpackage.pdf (last access: 30 August 2014), 2008.

Swanson, B. and Claar, J.: The history and development of agricultural extension, in: Agricultural Extension: A Reference Manual, edited by: Swanson, B. E., Food and Agricultural Organization of the United Nations, Rome, 1984.

Syngenta: Agricultural Extension, Improving the livelihood of smallholder farmers, available at: http://www. syngentafoundation.org/index.cfm?pageID=594 (last access: 5 September 2014), 2014.

Thomas, D. S., Twyman, C., Osbahr, H., and Hewitson, B.: Adaptation to climate change and variability: farmer responses to intraseasonal precipitation trends in South Africa, Climatic change, 83, 301-322, 2007.

TFCC - Task Force on Climate Change: Planning Commission, Government of Pakistan, http://pc.gov.pk/usefull_links/ Taskforces/TFCC_Final_Report.pdf (last access: 10 August 2014), 2010.

Weber, E. U.: What shapes perceptions of climate change?, Wiley Interdisciplinary Reviews: Climate Change, 1, 332-342, 2010. 